\title{
4. Cellular composition of the plant body
}

\author{
4.1 The individual cell
}

Single cells can only be observed through microscopes. The cell is anatomically and physiologically complex. It principally consists of protoplasts, which contain various organelles, the vacuole and the cell wall. The following section introduces elements that are visible under normal and polarized light without special microscopic equipment.
Shown here are different cell types, cell walls, nuclei and plastids and ergastic substances (non-protoplasm material such as crystals, resins, tannins etc.).

The following figure schematically shows all components. Nuclei, plastids, vacuoles and cell walls are recognizable by light microscopy.

Nuclei

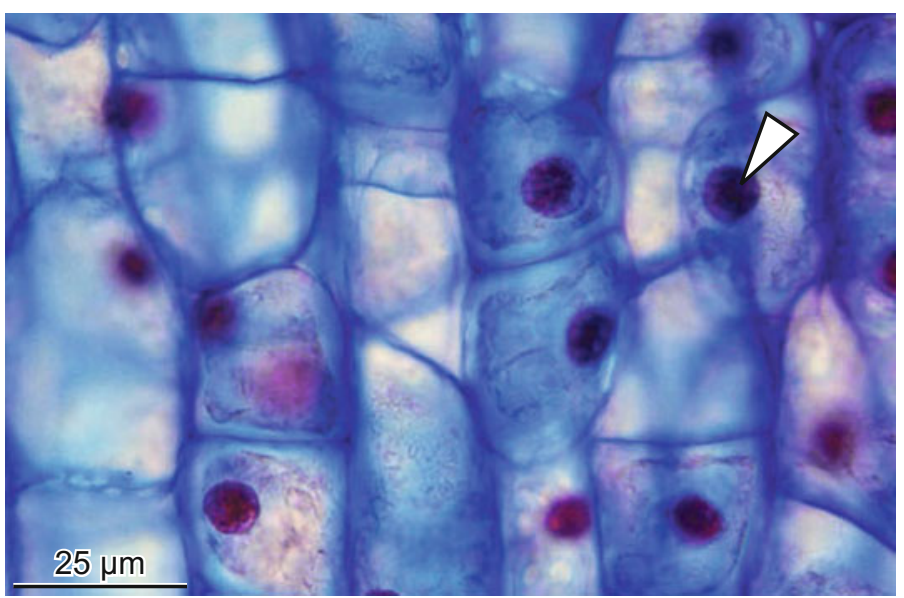

4.1 Nuclei in meristematic cells with unlignified cell walls in Viscum album.

\section{Plastids}

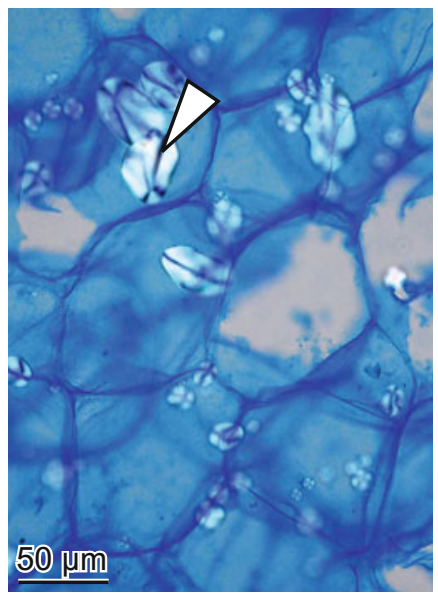

4.3 Starch grains in large unlignified cells of Solanum tuberosum, polarized light.

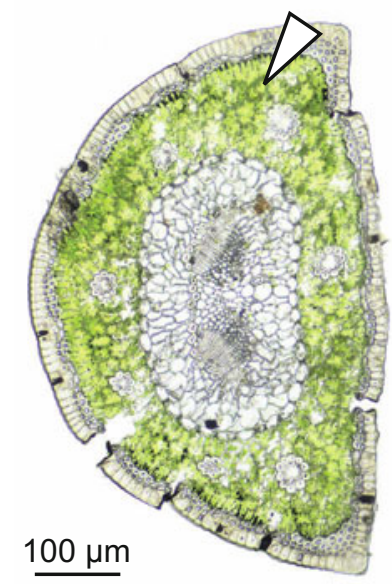

4.4 Chloroplasts in peripheral cells of a needle of Pinus nigra.

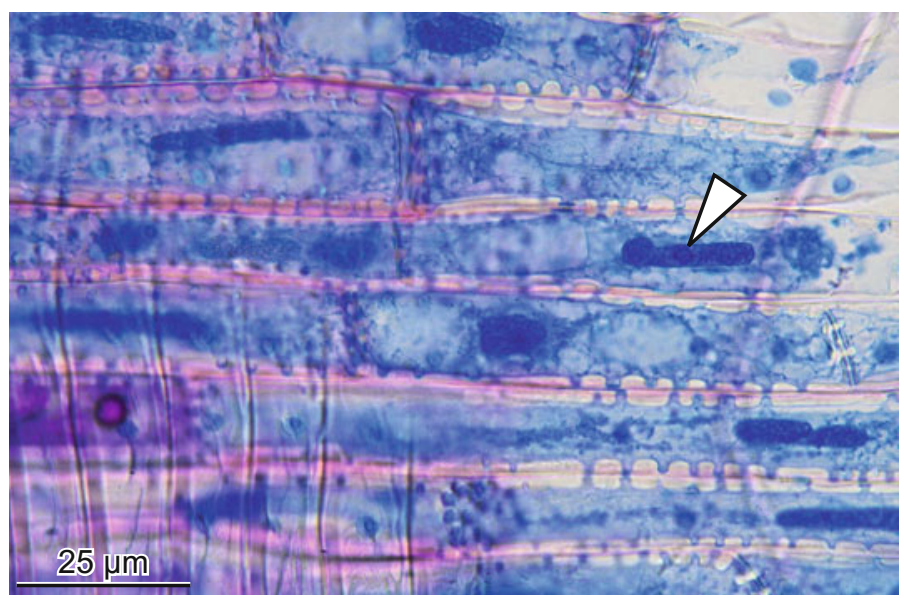

4.2 Nuclei in adult cells in a xylem ray with lignified, thick walls in Picea abies.

\section{Ergastic substances}

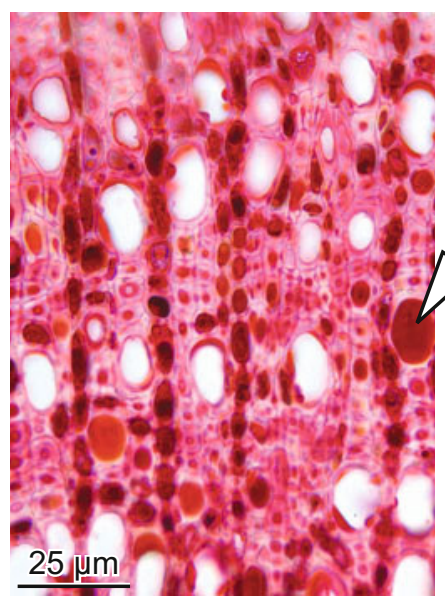

4.5 Tannins in heartwood cells of the dwarf shrub Globularia cordifolia.

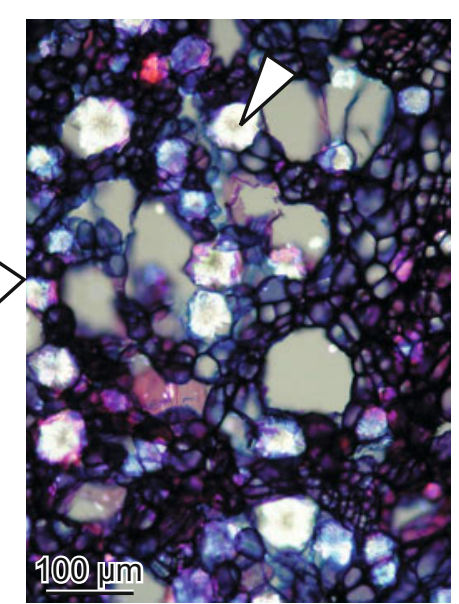

4.6 Calcium oxalate crystals in enlarged parenchyma cells of the herb Gypsophila repens, polarized light. 


\subsection{Meristematic initials - The source of new cells}

Meristematic cells are anatomically undifferentiated and capable of dividing. Meristematic initials are living cells and have exclusively unlignified, thin primary walls. Primary meristematic initials are arranged in the tip of longitudinal shoots and roots (vegetation point). Secondary meristematic initials are arranged around the shoot and are the initial part of the cambium. Tertiary meristematic initials are a product of parenchyma cells in the bark. They represent the cork cambium (phellogen).
Primary meristems produce the cortex and the pith in stems. Secondary meristems (cambium) are a product of primary meristems and occur around stems where they produce the xylem and phloem. Tertiary meristems are a product of living parenchyma cells in the cortex, the phloem, and rarely in the xylem, where they produce mainly cork cells. Meristematic cells have no pits.
Primary meristems in shoots \& roots

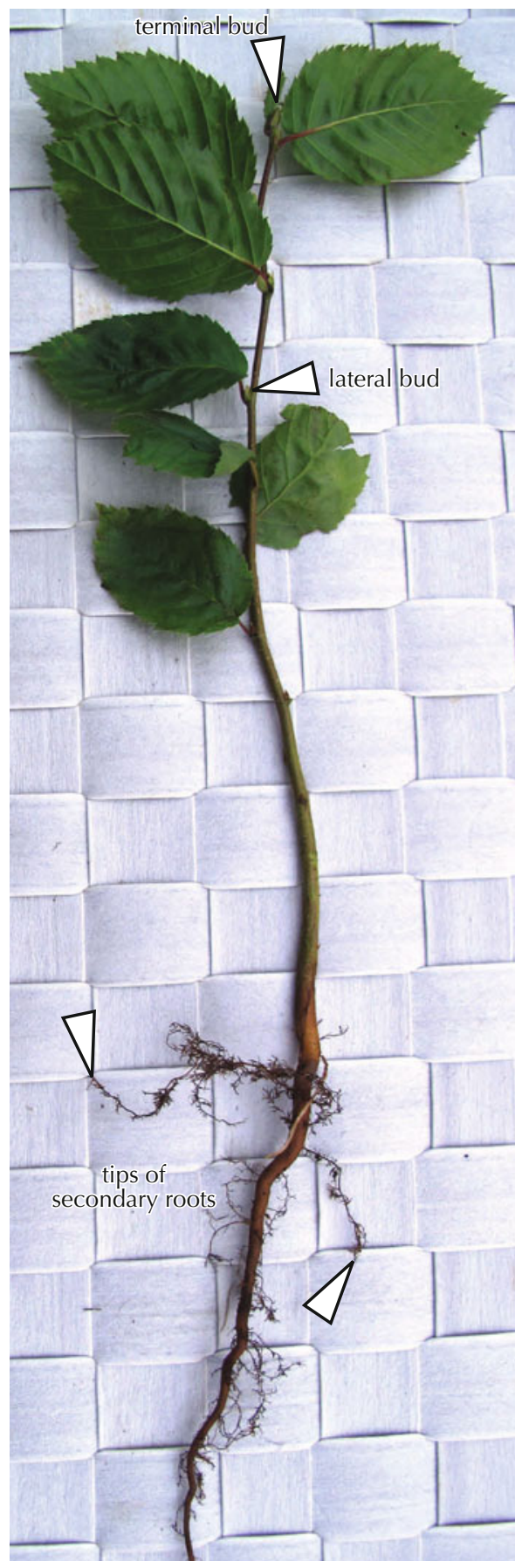

4.7 Primary meristems in a sapling of Carpinus betulus.

Embryonic cells in shoot tips, primary meristem

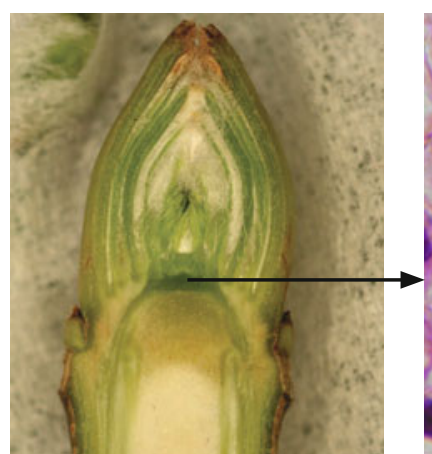

4.8 Location of a primary meristem in a shoot tip Acer pseudoplatanus.

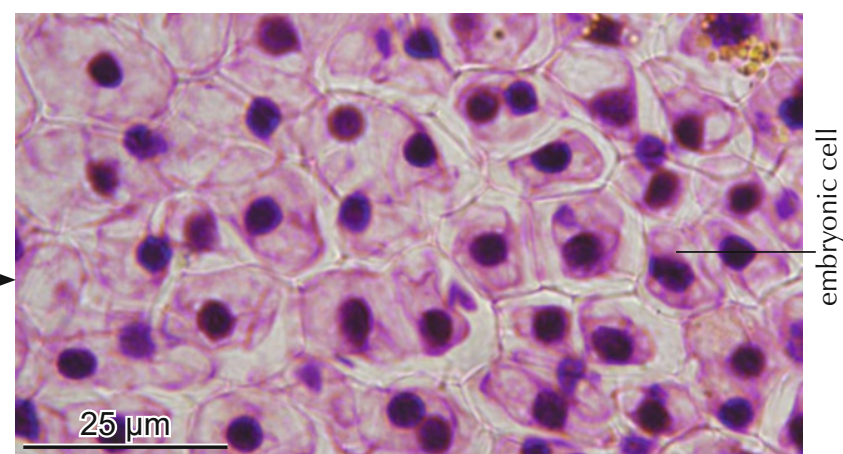

4.9 Microscopic aspect of embryonic cells in the primary meristem in a shoot of Larix decidua.

\section{Embryonic cells in root tips, primary meristem}

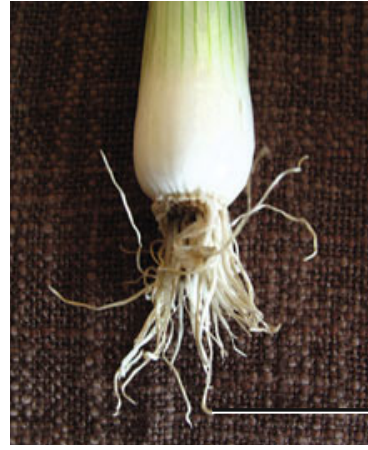

4.10 Macrosopic aspect of the location of a primary meristem in a root tip of Allium ursinum.

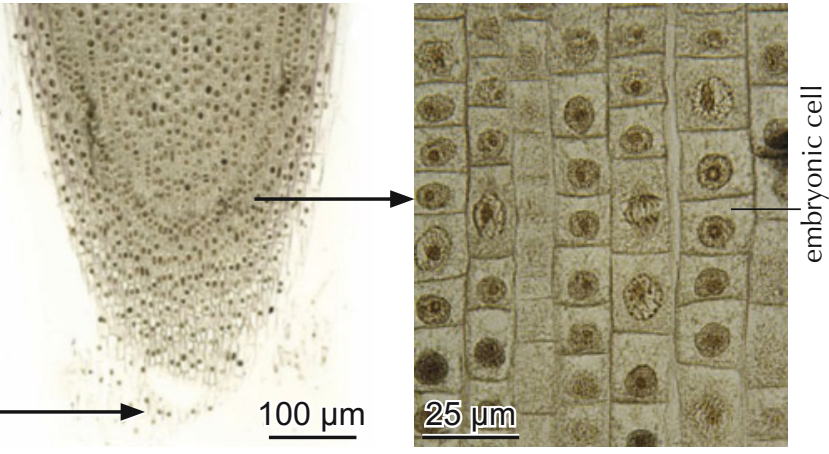

4.11 Embryonic cells in the primary meristem in a root of Allium ursinum.

\section{Juvenile cells in secondary and tertiary meristems}

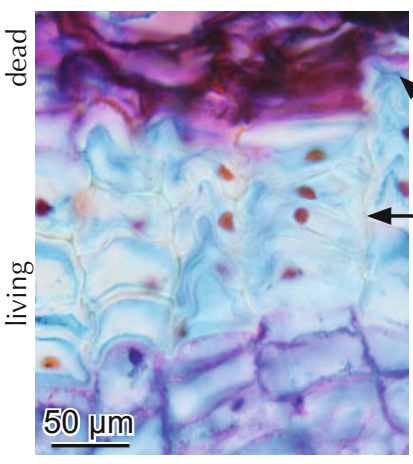

4.12 Cells with nuclei in the tertiary meristem (phellogen) of Paeonia suffruticosa.

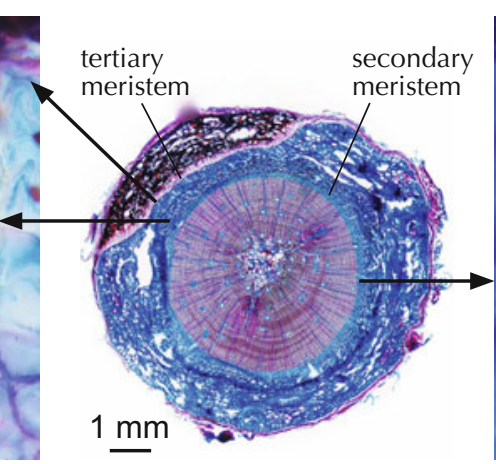

4.13 Location of the secondary and tertiary meristems in Pinus mugo.

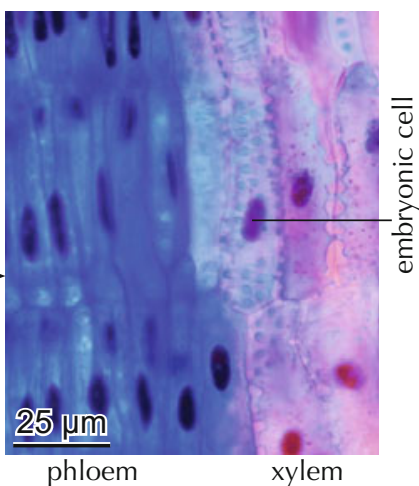

4.14 Juvenile cells with nuclei in secondary meristem and adjacent xylem/phloem in Viscum album. 


\subsection{The cuticula - Protection against dehydration}

Cells exposed to the air, mostly epidermis cells, protect internal plant cells from dehydration. The cuticle at the external surface of the epidermis is an effective transpiration protection layer. Leaf surfaces with flat and compact cuticles are glossy and those with rippled cuticles are matte.

Cuticles mainly consist of pectin and cutin. The soluble extract polymerizes after the full development of the organs. Cuticles occur on leaves and young stems without periderm in all taxonomic units of vascular plants. They are absent in roots.
Cuticles are generally absent in water plants, they are thin in plants growing in shadowy conditions, and thick in plants at dry sites. The structure of the surfaces is homogeneous, layered or even granular. Chemically related to cutin are waxes, suberin and sporopollenin.

\section{Thin and thick cuticles}

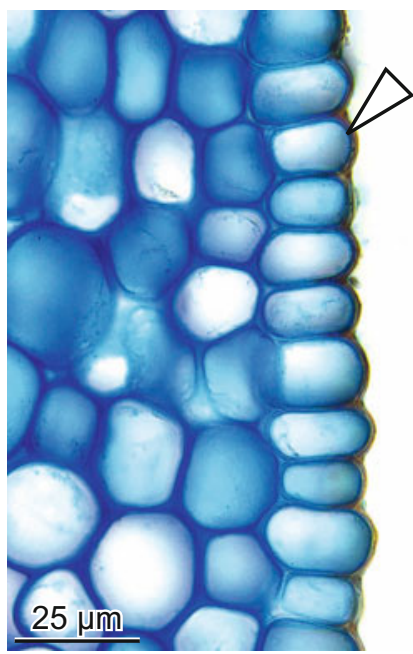

4.17 Stem of Ipomaea tricolor on a shadowy site, with a thin cuticula.

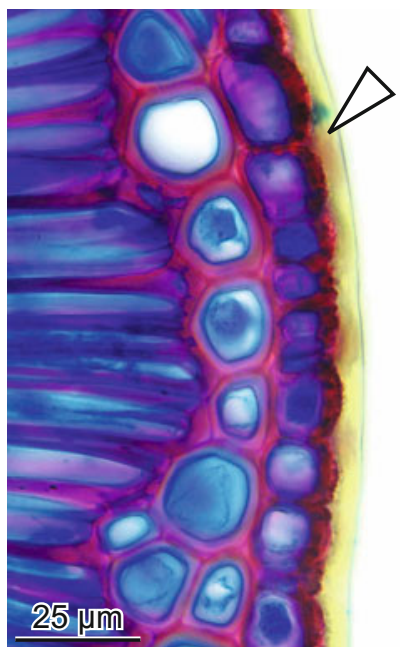

4.18 Leaf with a thick, unstructured cuticula of Zamia sp. on a very dry site.
Rippled cuticles

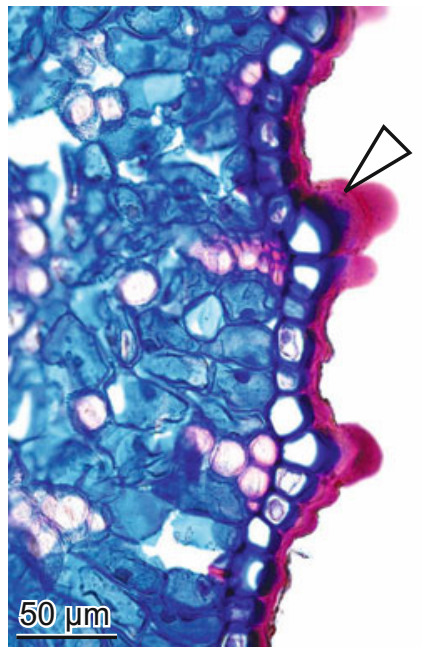

4.19 Rippled cuticula of an annual twig of Ephedra viridis.

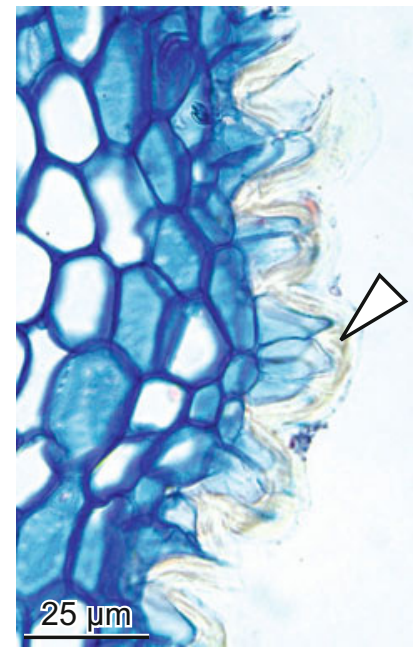

4.20 Thick, rippled cuticula on the underside of a leaf of Buxus sempervirens on a dry site.

Structured cuticulae

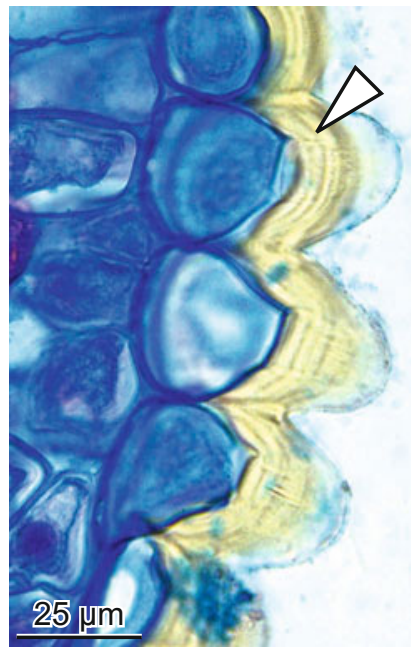

4.21 Layered cuticula on a young stem of the mistletoe Viscum album.

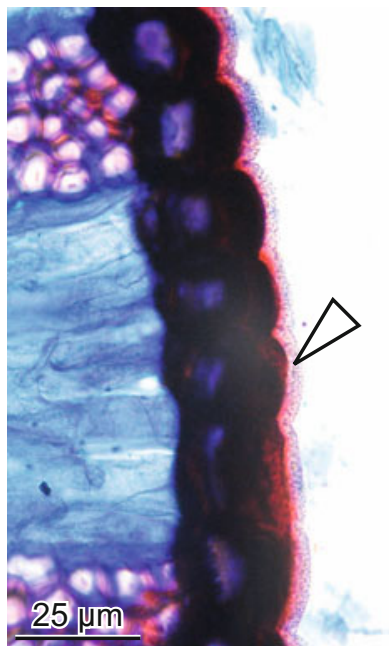

4.22 Granulated cuticula on a leaf of Welwitschia mirabilis. 


\subsection{Epidermis - The skin of plants}

The epidermis covers the products of primary meristems of most plants. Examples of stems and leaves from ferns, conifers, monocotyledonous and dicotyledonous plants are shown. Epidermis cells form a uniseriate layer of generally isodiametric cells at the periphery of primary plant bodies. Epidermis cells protect internal tissues from dehydration. Local cell wall expansion and cell division form bulliform cells or a variety of trichoms and hairs with special functions.
The epidermis of green plants is punctuated with stomata, allowing gas exchange between the atmosphere and the plant tissue. Since epidermis cell walls are transparent, photosynthesis is possible in all cells below it even when the vacuoles are filled with red-stained anthocyanins (pigments).
Macroscopic aspect of terrestrial plants

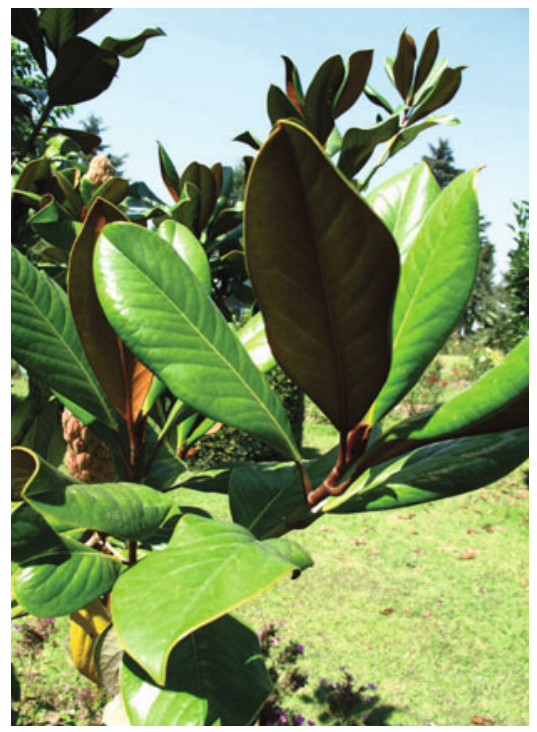

4.23 All leaves and young twigs of perennial plants are covered with an epidermis, like here in Magnolia grandiflora.

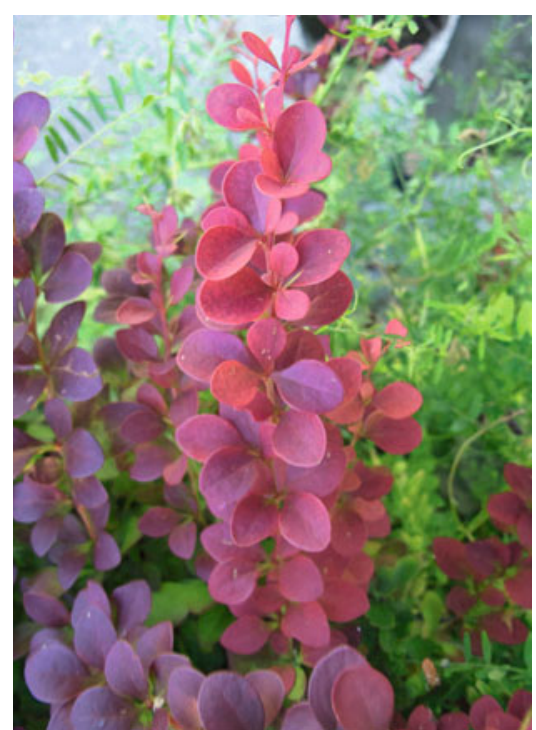

4.24 Red leaves appear red because the epidermis cells are filled with the red pigment anthocyanin, like here in Berberis sp.
Epidermis cells in a red leaf

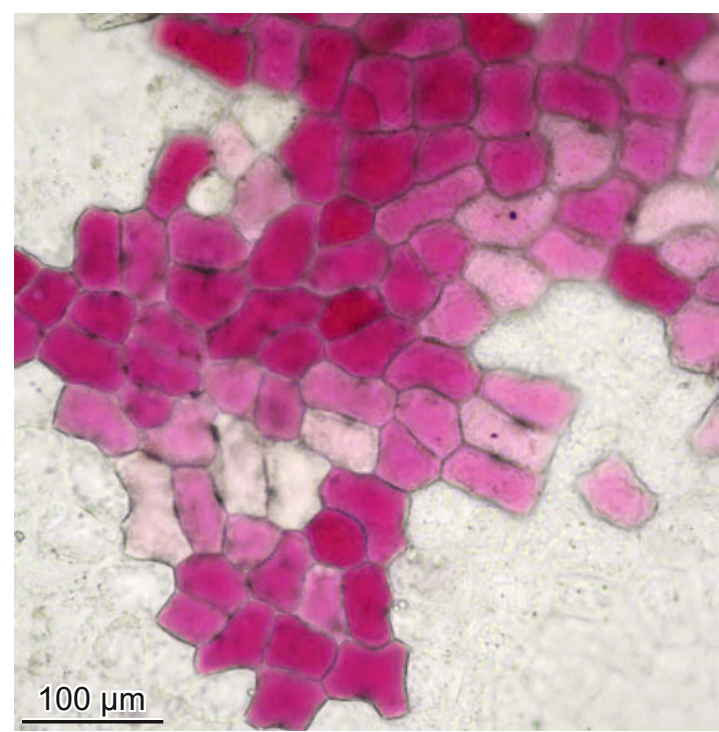

4.25 Vacuoles are filled with the red pigment anthocyanin in the epidermis of a fruit of Euonymus europaeus.
Water plants

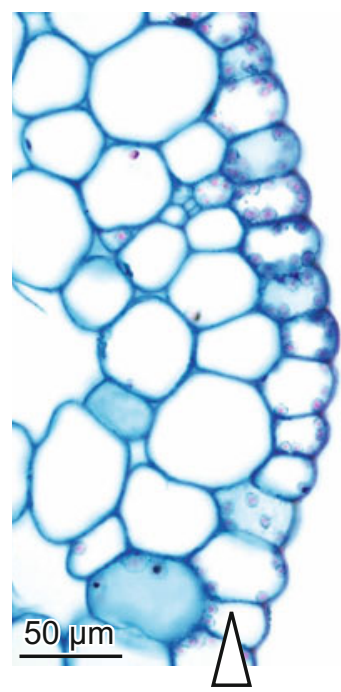

4.26 Very thin-walled epidermis in the water plant Elodea canadensis.

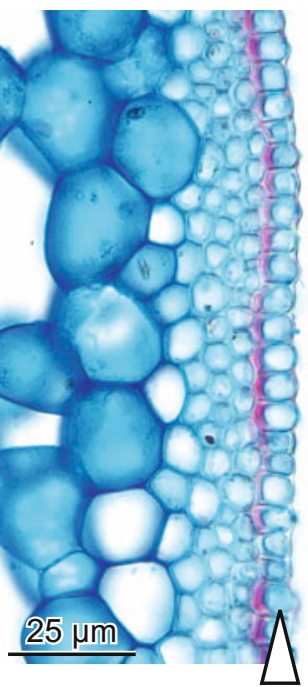

4.27 Partially lignified epidermis in the swamp plant Scheuchzeria palustris.

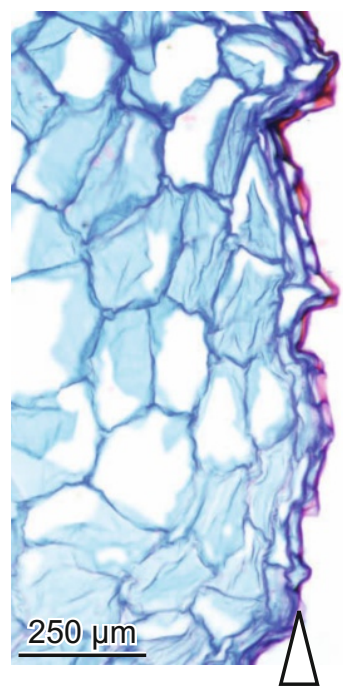

4.28 Externally lignified epidermis of the herb Adoxa moschatellina on a wet site.
Terrestrial plants

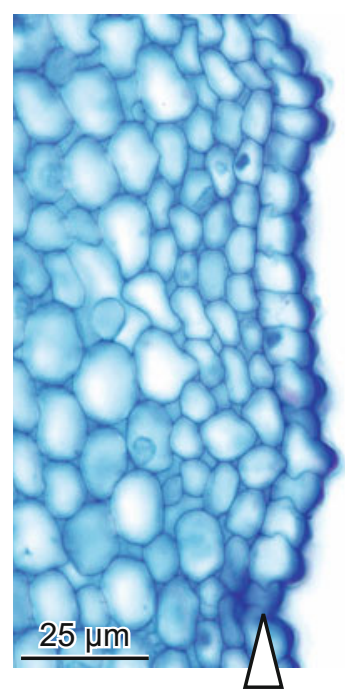

4.29 Externally thick-walled, unlignified epidermis. Young shoot of Asparagus sp. on a dry site.

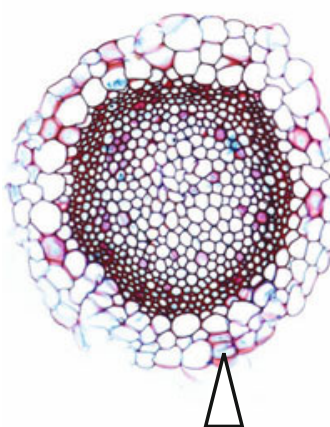

$100 \mu \mathrm{m}$

4.30 Very thin-walled epidermis in a Sphagnum sp. 


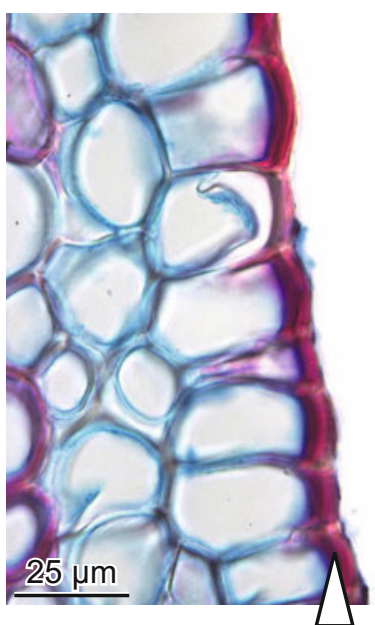

4.31 Externally thick-walled and lignified epidermis of the herb Psilotum nudum on a wet site.

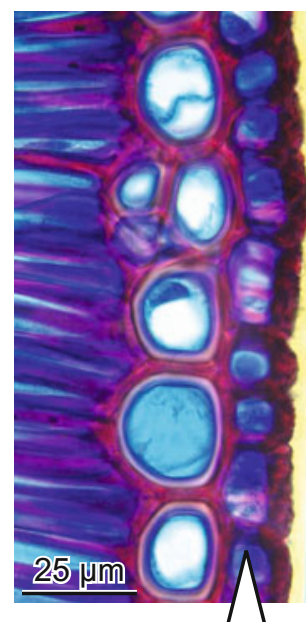

4.32 Very thick-walled epidermis in Zamia sp.

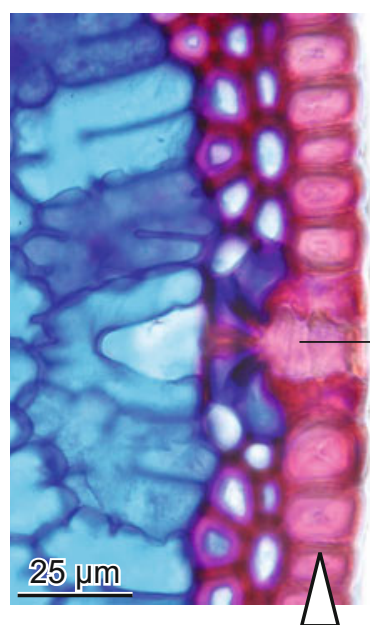

4.33 Thick-walled, lignified epidermis on a needle of the conifer Pinus nigra.

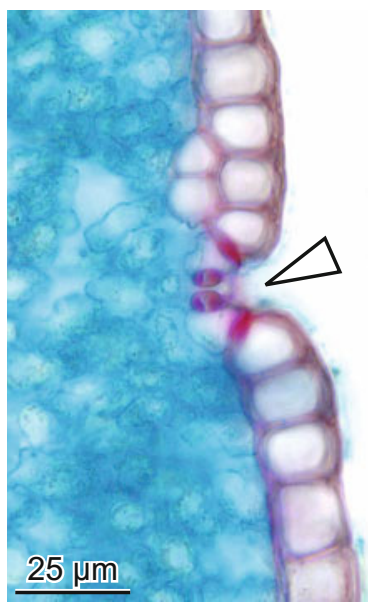

4.34 Sunken stoma in the epidermis of Elymus farctus.
Anatomy of elongated epidermis cells

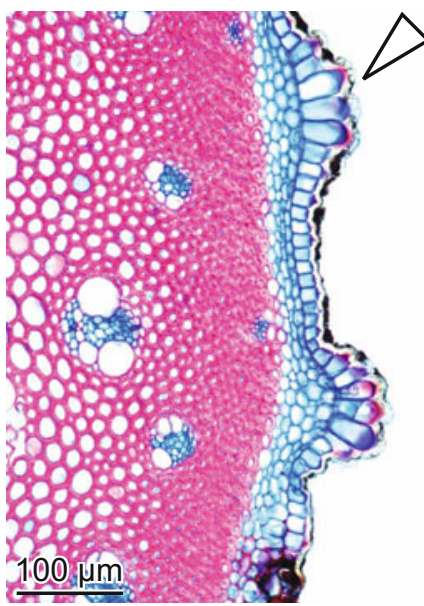

4.35 Locally enlarged epidermis cells in Asparagus scoparius.

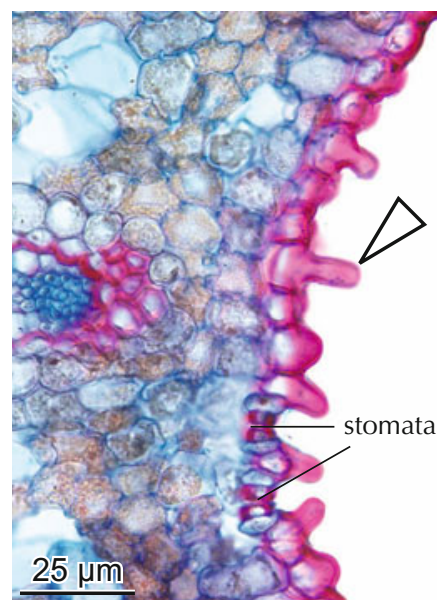

4.36 Bulliform lignified epidermis on a shoot of the monocotyledonous Carex glareosa.

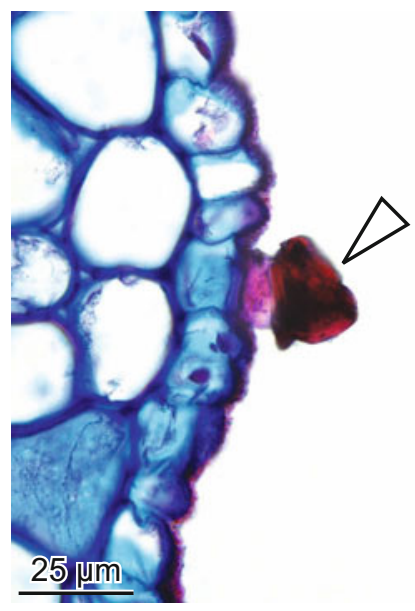

4.37 Excretion in Lysimachia vulgaris
Trichoms

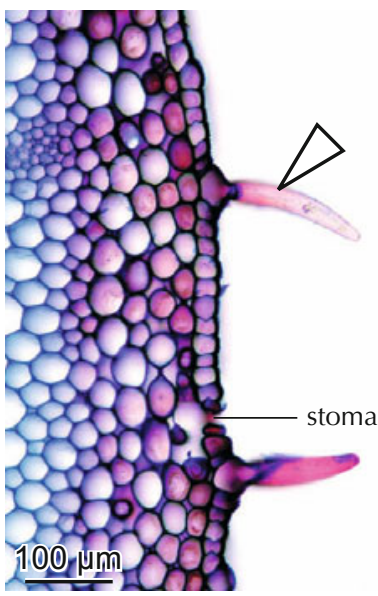

4.39 Unicellular hairs in Lilium martagon.

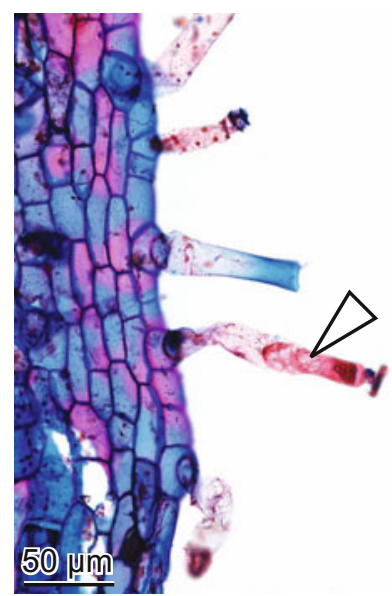

4.40 Bicellular hairs in Scrophularia peregrina.

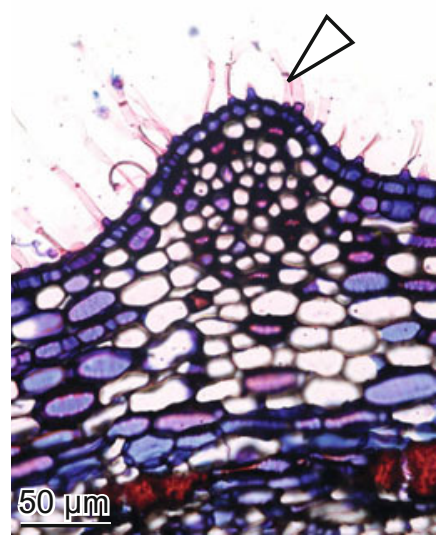

4.41 Multicellular hairs in Ptilostemon chamaepeuce.
Rhizoids

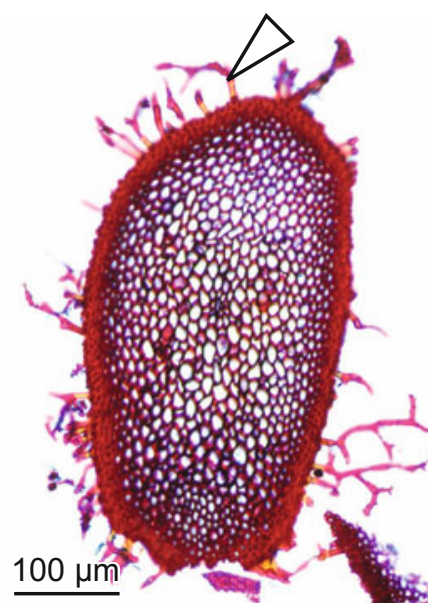

4.42 Stem of the moss Thuidium tamariscinum. 


\subsection{Collenchyma - Local peripheral stability}

Collenchyma functions as a stabilizing element in edges and ridges of herbaceous plant stems of various genera in dicotyledonous and monocotyledonous plants. They are a product of primary meristems and occur in the cortex of stems. Collenchyma cells are similar to parenchyma cells but are normally longer and have pointed axial ends. Characteristic are the partially thickened primary cell walls. The walls contain cellulose, and a large amount of pectin, which is indicated by blue to purple staining with Astrablue/Safranin. The appearance largely varies: some cells are only slightly and some intensively thickened (lamellar collenchyma) and some only in the angles (angular collenchyma). At least some cells contain protoplasts and nuclei.

\section{Collenchyma occurs mainly in the cortex of dicotyledonous plants}

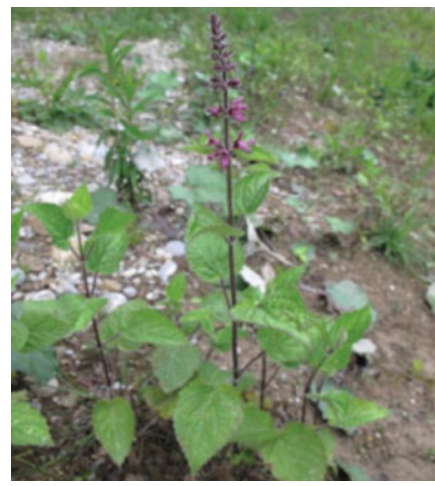

4.43 Stachys sylvatica, a Lamiaceae with quadrangular stems.

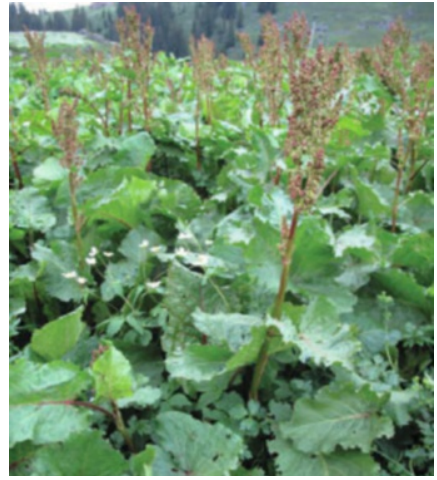

4.46 Rumex alpinus, a Polygonaceae with longitudinally ribbed annual shoots.

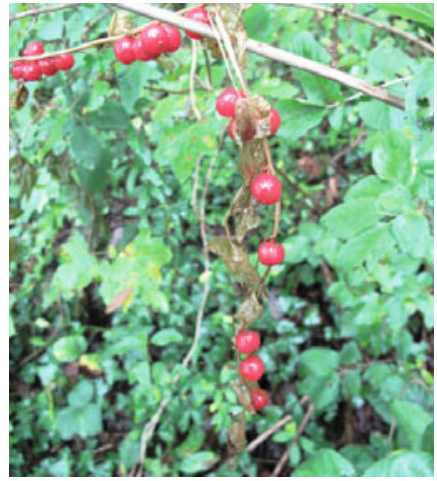

4.49 Tamus communis, a monocotyledonous plant, belonging to the Dioscoreaceae, with lightly-ribbed annual liana-like shoots.

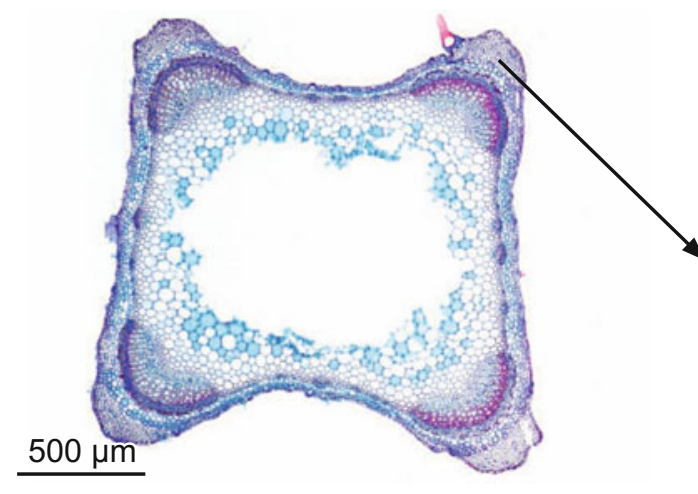

4.44 The quadrangular stem of Stachys sylvatica is stabilized by collenchyma in the cortex.

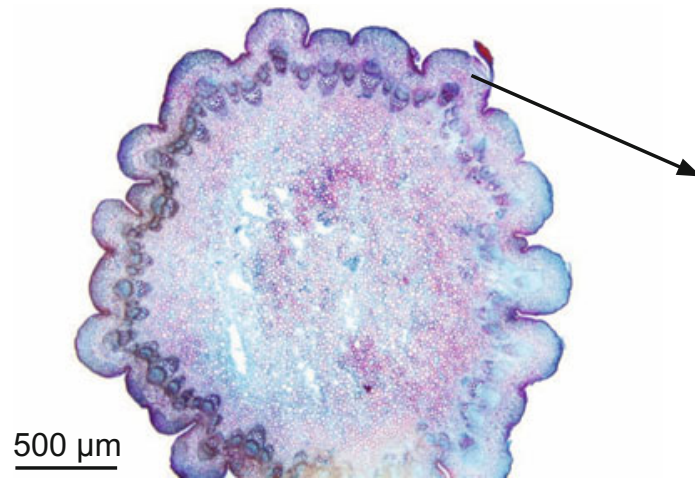

4.47 The ridges in the stems of Rumex alpinus are stabilized by collenchyma in the cortex.

\section{Collenchyma is rare in monocotyledonous plants}

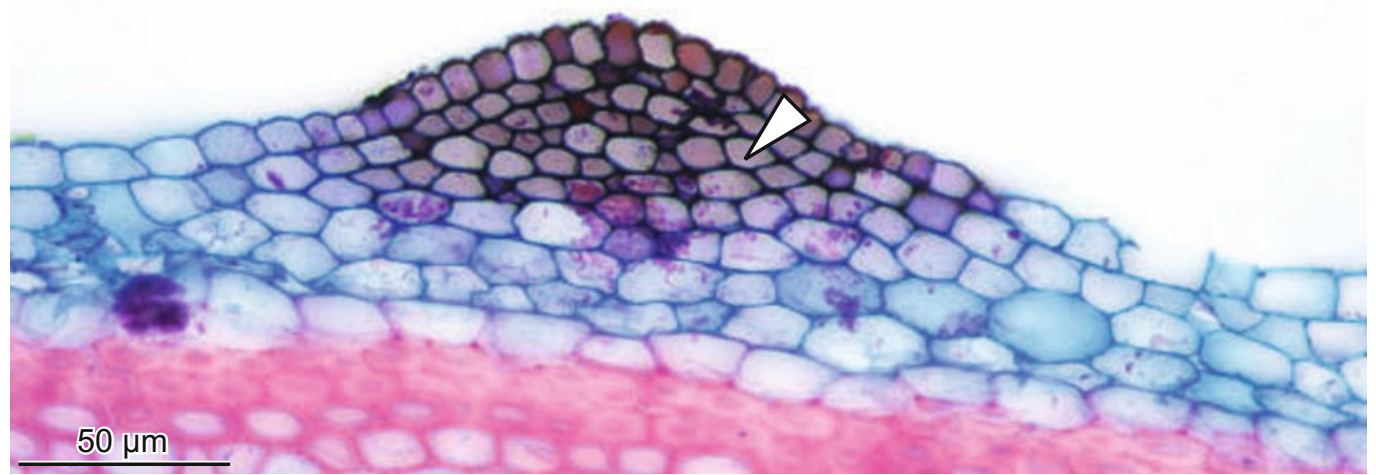

4.50 Morphologically hardly differentiated collenchyma in Tamus communis. Only the different reaction to the Astrablue/Safranin staining (purple coloring) indicates the collenchyma. 


\subsection{Parenchyma cells - Storage and repair}

Humans would not be able to exist without plant parenchyma cells because their cell contents, especially carbohydrates, are essential components of our diet. Parenchyma cells are present in all plants. They are mostly small isodiametric or slightly elongated cells without pointed ends. Cell walls of parenchyma cells are thin- or thin- to tick-walled, lignified or unlignified and perforated with simple pits. Parenchyma cells primarily function as storage cells. Living parenchyma cells are totipotent. They have the potential to regenerate new cell types or entire plants under suitable environmental conditions. They play an essential role in regeneration processes after injury (see Chapter $10)$.

Parenchyma cells are part of stems, roots, leaves, flowers, fruits and seeds. Abundant amounts of parenchyma cells occur in thickened belowground organs. The life span of parenchyma cells of perennial plants is normally very long. Ray-parenchyma cells can live for more than 100 years in the sapwood of conifers or more than 200 years in dwarf shrubs of the arctic.

Parenchyma cells occur in all terrestrial plants

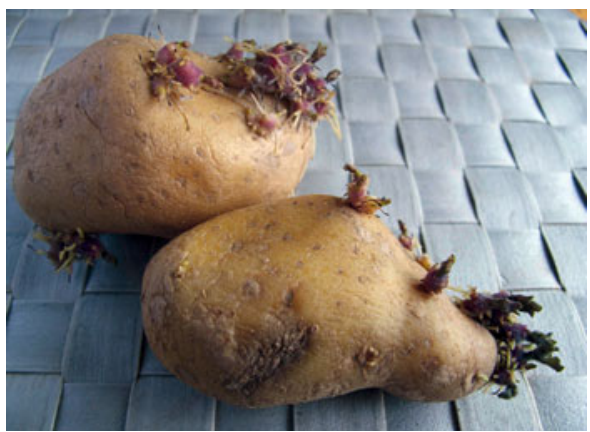

4.51 Potatoes (Solanum tuberosum) consist mainly of parenchyma cells. They are able to produce new shoots.

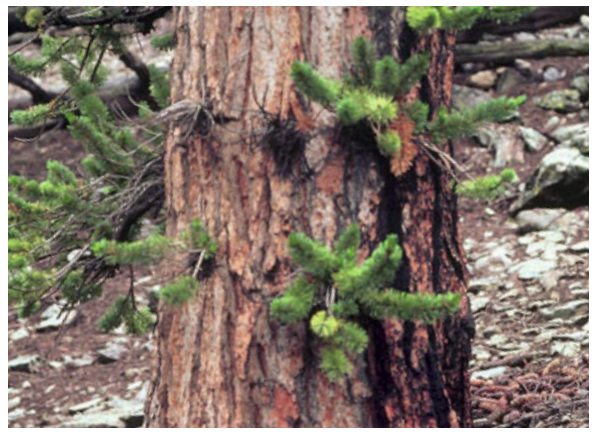

4.52 Approx. 5\% of the xylem in trees are parenchyma cells. Parenchyma cells in the phloem can change their mode of behavior and form new shoots.

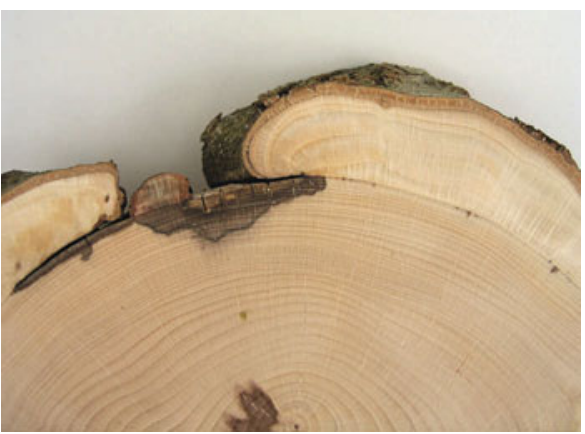

4.53 Scar on the stem of Acer pseudoplatanus. Living parenchyma cells repair wounds and protect the stem against destructive organisms.

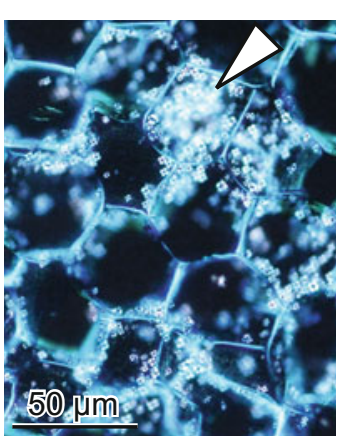

4.54 Parenchyma cells are mostly filled with starch grains in the rhizome of Anemone nemorosa, polarized light.

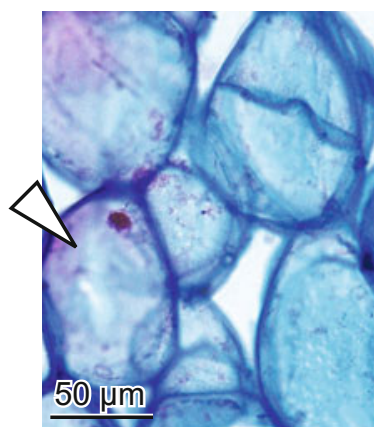

4.59 Water-storing parenchyma cells in the succulent Sedum acre.

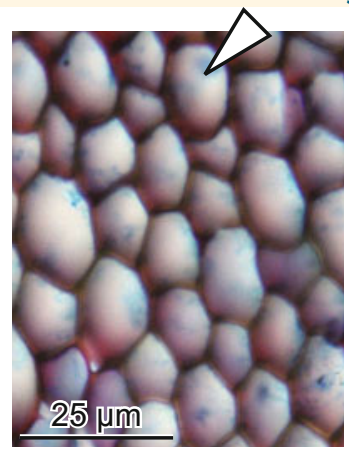

4.55 Isodimetric parenchyma cells in the stem of the moss Polytrichum commune.

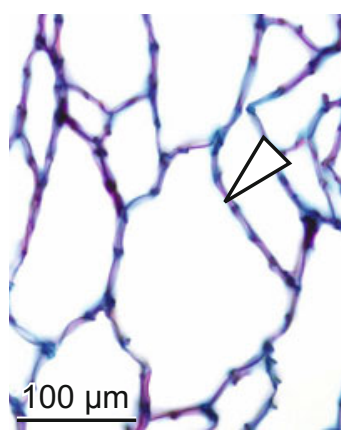

4.60 Very small parenchyma cells between air-conducting spaces in the pith of swamp plant Scirpus radicans.

Shape of parenchyma cells

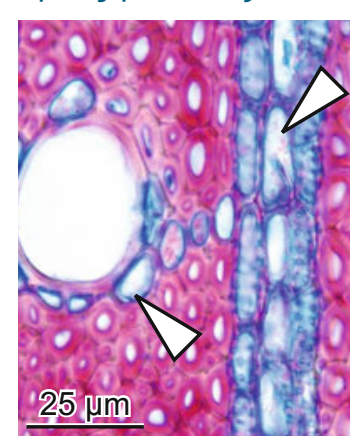

4.56 Parenchyma cells in the xylem of Sonchus lep tophyllus. Axially sectioned cells are round, radially sectioned cells are elongated.

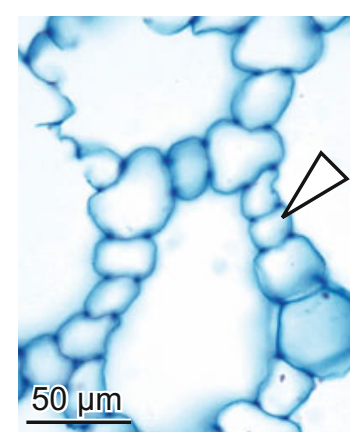

4.61 Parenchyma cells surround air canals in the cortex of the swamp plant Orontium aquaticum.

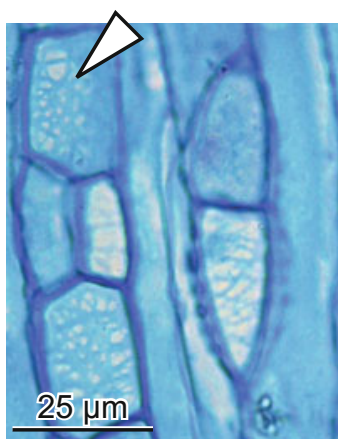

4.57 Simple pits are characteristic for parenchyma cells. Ray cells in the bark of Paeonia suffruticosa.

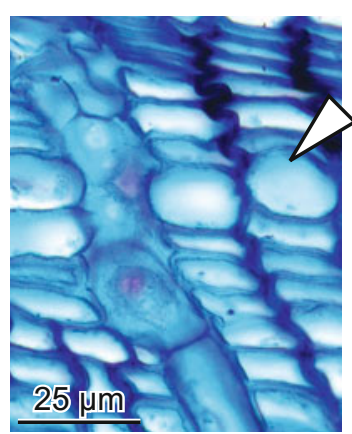

4.62 Parenchyma cells alternate with sieve cells in the bark of conifers such as Abies alba.

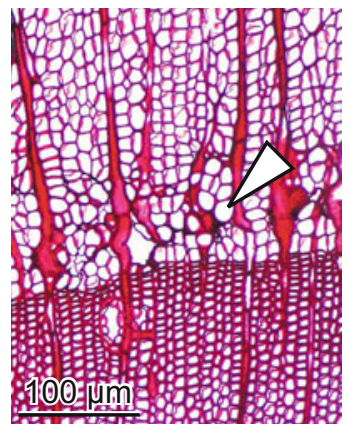

4.58 Irregularly formed parenchyma cells, the callus cells, appear after wounding in Picea abies.

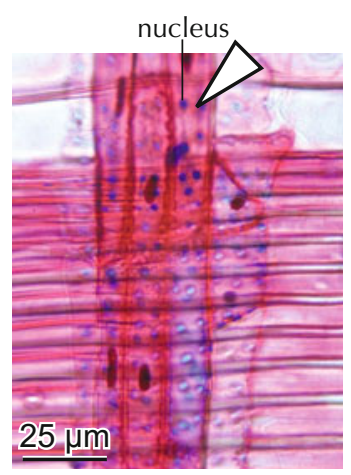

4.63 Long-living parenchymatic ray cells with nuclei (blue) in Picea abies. 


\subsection{Fibers and tracheids - Stabilisation and water conduction}

Many wooden products, e.g. beams, boards, firewood and paper, are substantial basics of our daily life. The main function of fibers is stabilization, while tracheids are stabilizing and conduct water.

Fibers and tracheids are long cells with elongated, pointed tips. Tips are a result of post-cambial axial elongation. Fibers or tracheids occur in all growth forms and on all sites in spore plants (ferns, horsetails), in conifers, in monocotyledonous and dicotyledonous plants. They are part of annual and perennial stems of roots and leaves. Fibers have more or less thick, lignified cell walls. Characteristic is the presence of secondary walls. Pits in fibers are mostly simple or slightly bordered. Pits in tracheids are bordered (see Chapter 5.2, Fig. 5.19). Fibers occur in the xylem, phloem and cortex, tracheids only in the xylem.
Use of fibers

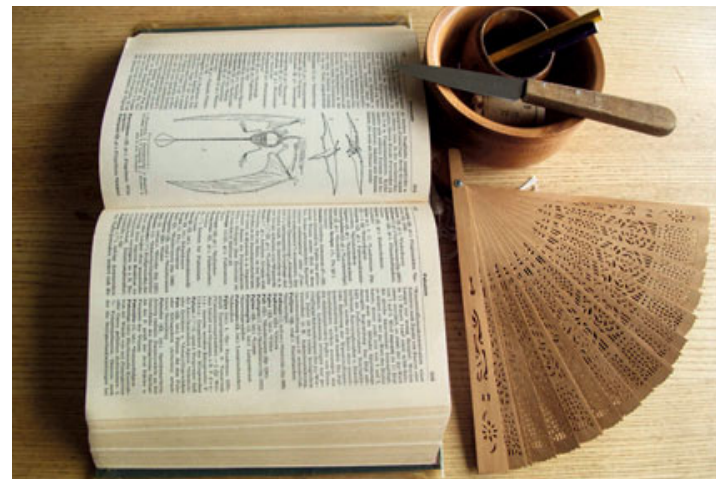

4.64 Fibers are omnipresent in human life in the form of wood products.

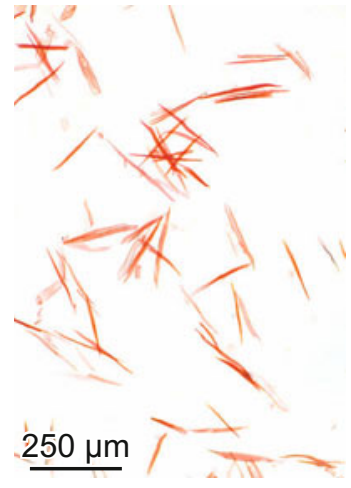

4.65 Short fibers (100$200 \mu \mathrm{m})$ in shrubs, such as Buxus sempervirens.

\section{Length of fibers}

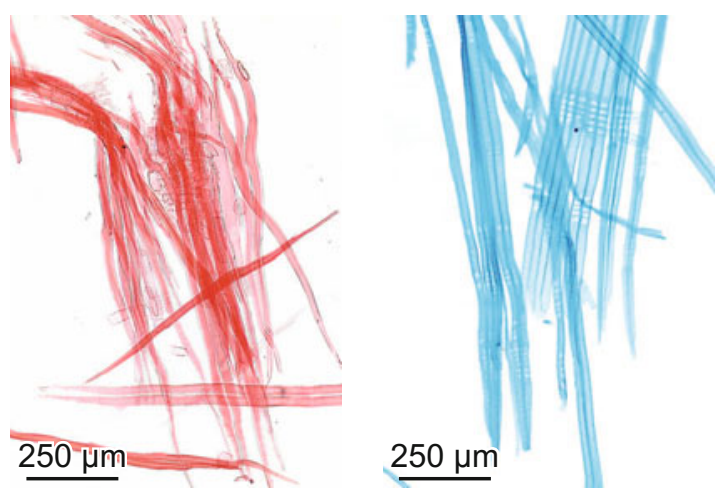

4.66 Long fibers (500-

$>1000 \mu \mathrm{m})$ in trees, such as Fagus sylvatica.
4.67 Long (1,000-3,000 $\mu \mathrm{m})$ de-lignified tracheids (used for pulp) in Pinus sylvestris.

Fibers occur in all vascular plants
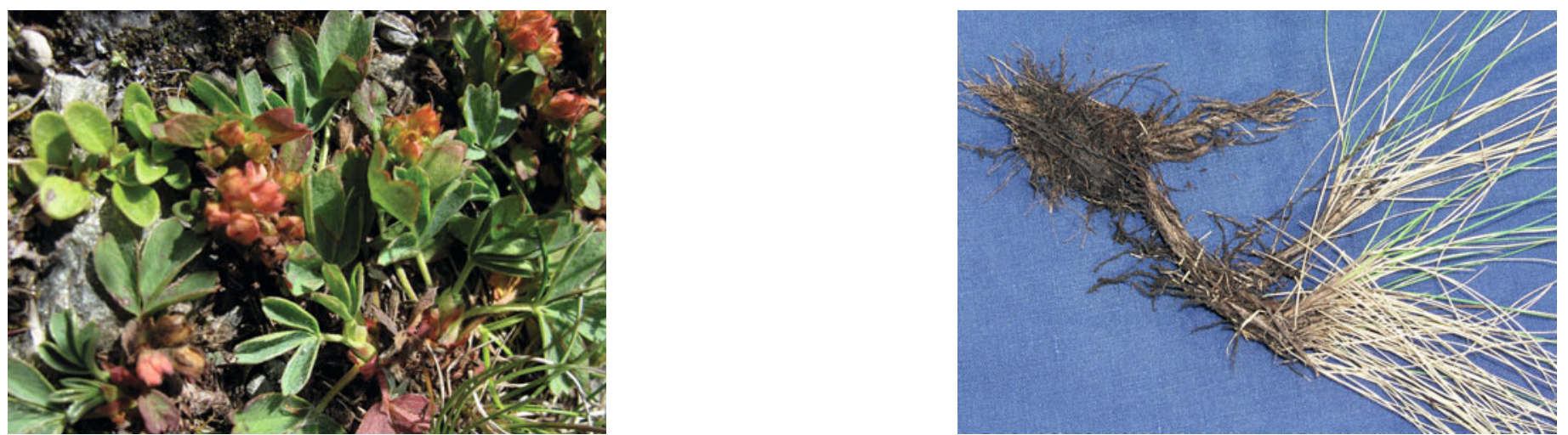

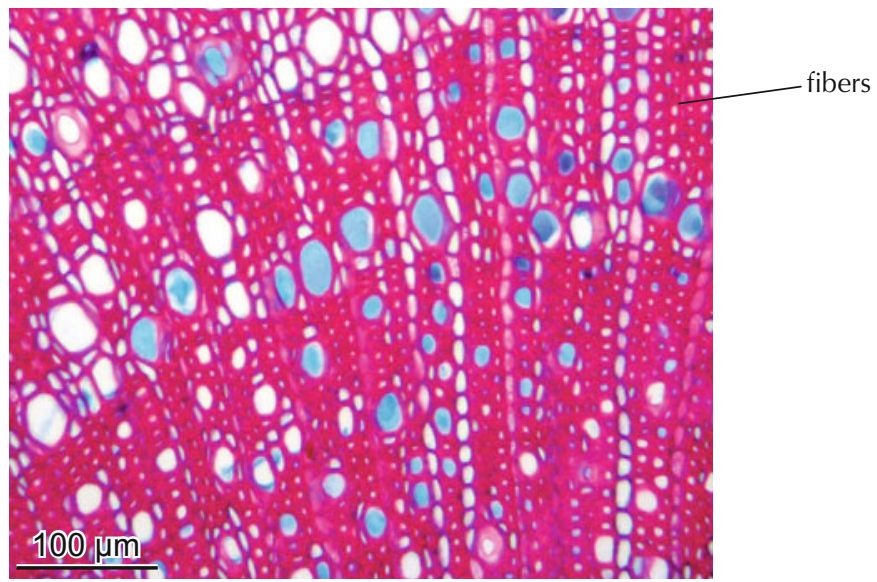

4.68 Fibers in stems of dicotyledonous dwarf shrubs like Sibbaldia procumbens.

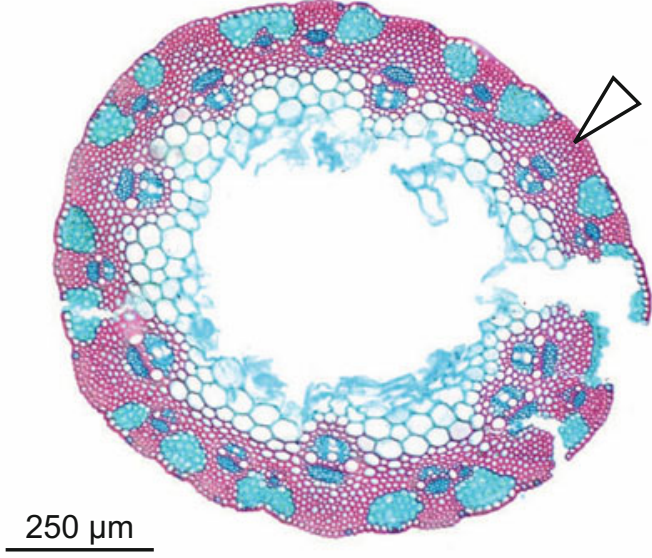

4.69 Fibers in culms and leaves of monocotyledonous herbs like Festuca alpina (top) or Festuca erecta. 


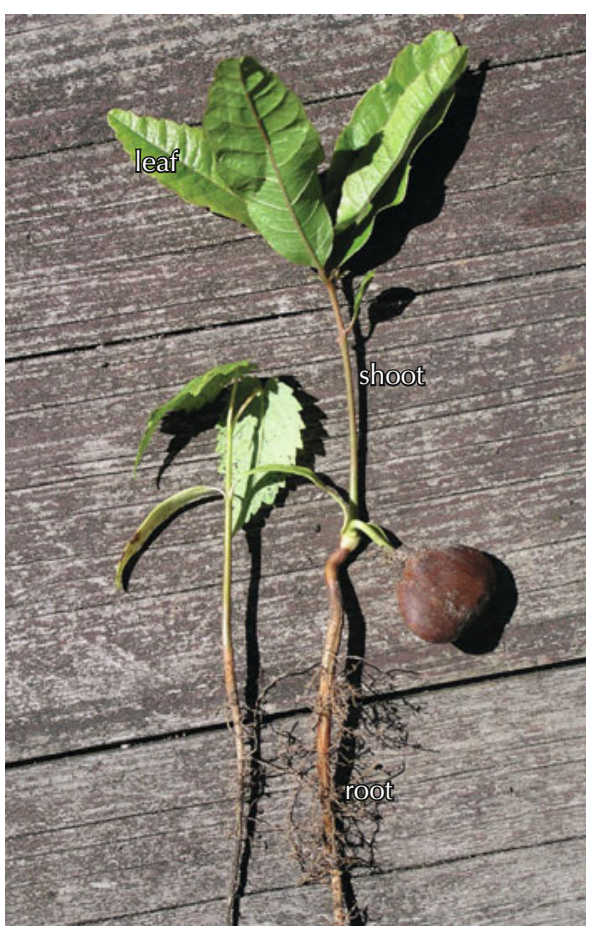

4.70 Fibers occur in stems, roots and leaves. Castanea sativa.

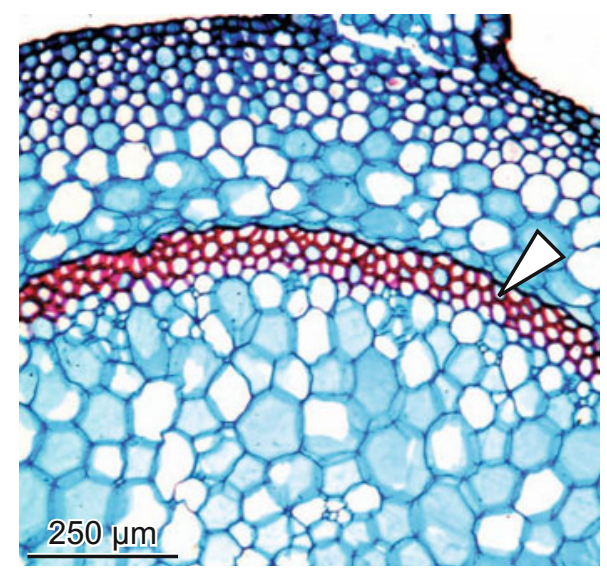

4.74 Fibers in a shoot (cortex) of Cucumis sativus.
Fibers occur in all parts of plants

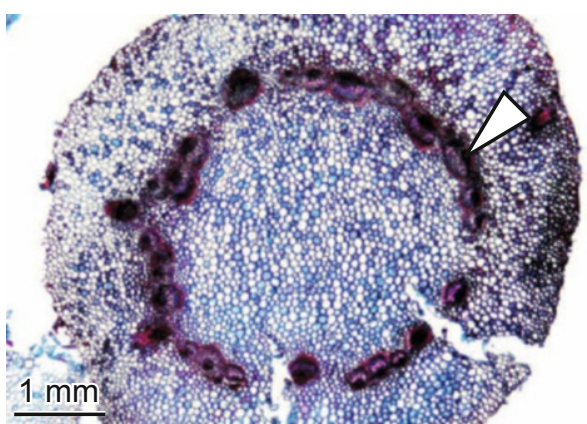

4.71 Fibers in a shoot of Ranunculus lanuginosus.

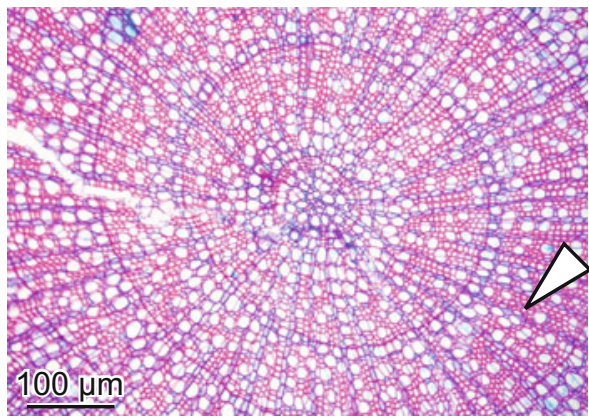

4.72 Fibers in a root of Ledum palustre.

Fibers occur in all parts of stems

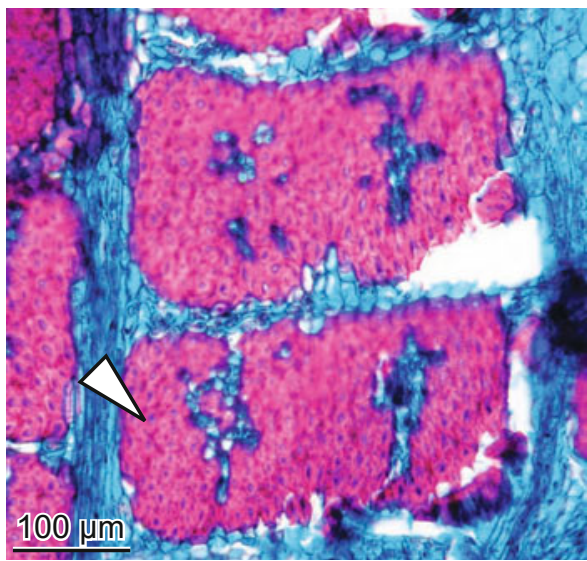

4.75 Fibers in the bark of Chrysothamnus parryi.

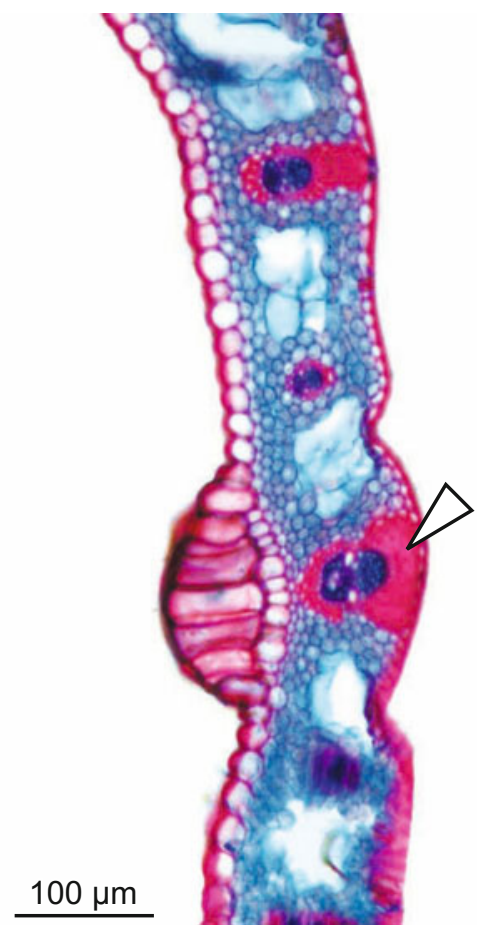

4.73 Fibers in a leaf of Carex sempervirens.

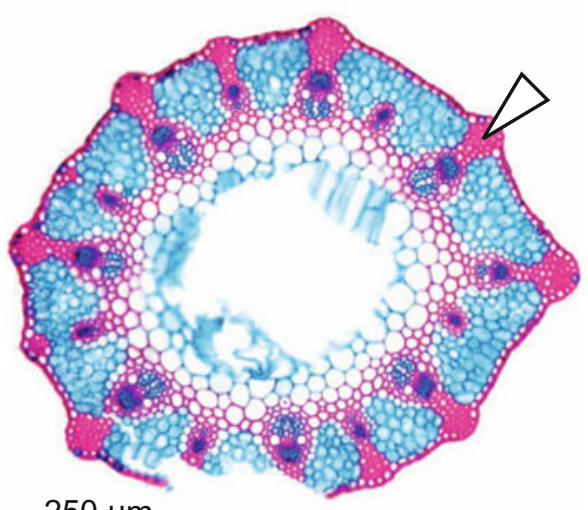

$250 \mu \mathrm{m}$

4.76 Fibers in a culm of Sesleria coerulea.

Various cell-wall thicknesses of fibers and tracheids

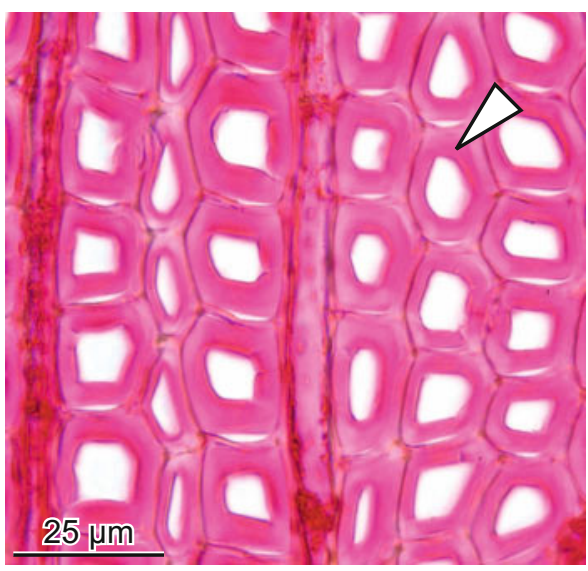

4.77 Thick-walled tracheids in Larix decidua.

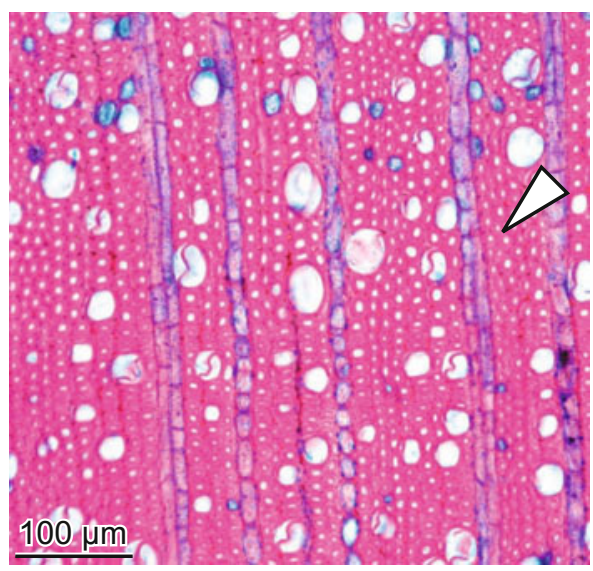

4.78 Thick-walled fibers in Eryobotrya japonica.

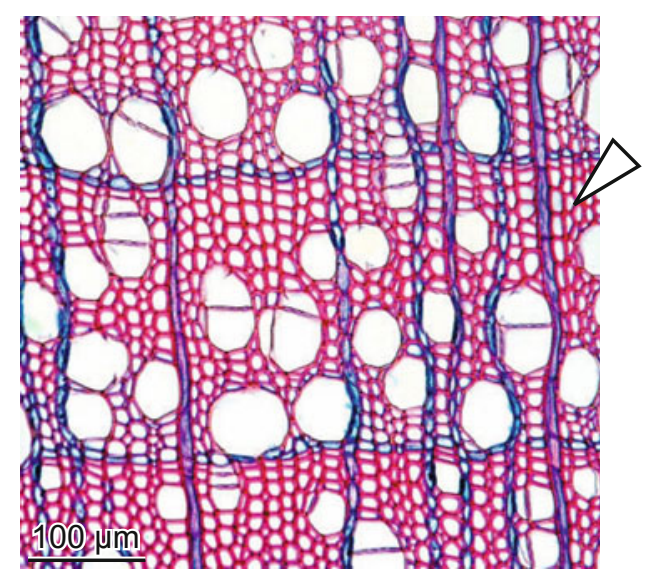

4.79 Thin-walled fibers in Salix foetida. 


\subsection{Sclereids in the bark - Extraordinary cell-wall thickening}

We notice sclereids when eating pears: The granules remaining between your teeth are sclereids. Sclereids are absent in the xylem but frequent in the phloem, cortex and pith of trees and herbs. They also occur in fruits and nut shells, and rarely in leaves. Characteristic for sclereids are the irregularly formed cells with thick, secondary walls, distinct simple pits and often distinct growth layers. A special case are star-like sclereids in the aerenchyma of the water lily (Nuphar sp). Sclereids in the bark normally occur in the non-conducting (adult) phloem and in rays. Sclereids originate from parenchyma cells with a shortterm accelerated growth of secondary walls.

\section{Sclereids in stems}

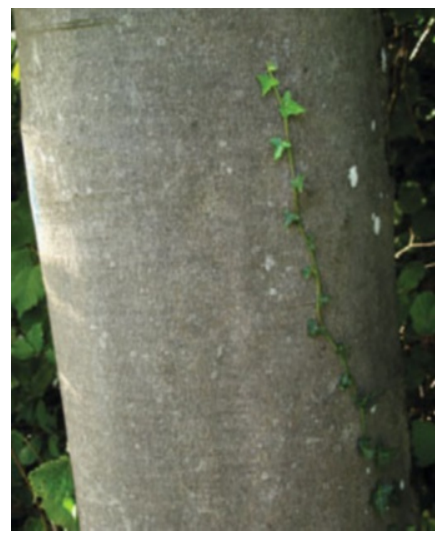

4.80 Hard bark of Fagus sylvatica.

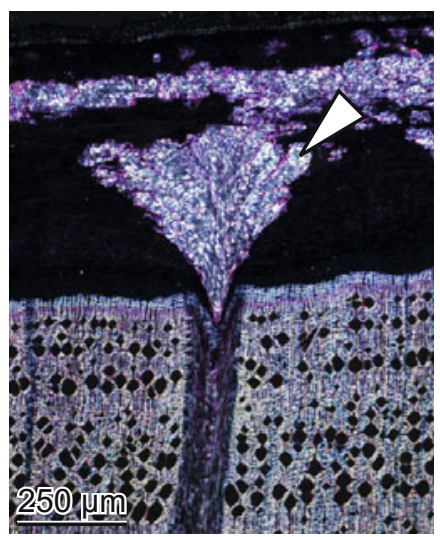

4.81 Many sclereids in a ray and the cortex in Fagus sylvatica, polarized light.

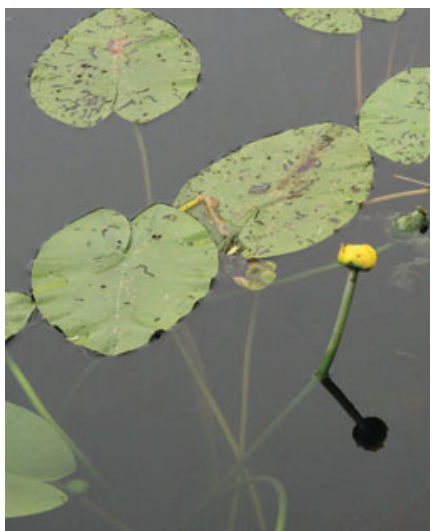

4.82 Flexible and soft culms and a petiole of the water lily Nuphar lutea.

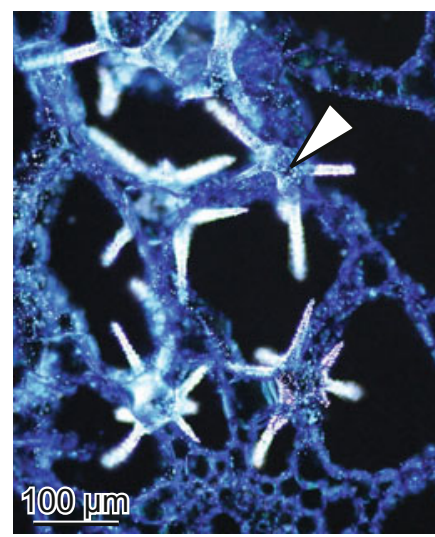

4.83 Star-like sclereids in air-conducting channels (aerenchyma) in Nuphar lutea, polarized light.

Sclereids in fruits

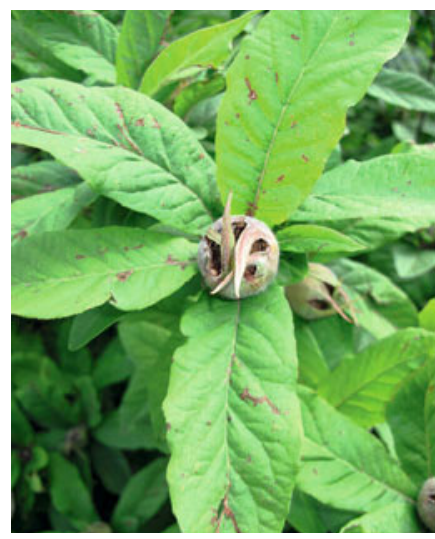

4.84 Fruit of Mespilus germanica.

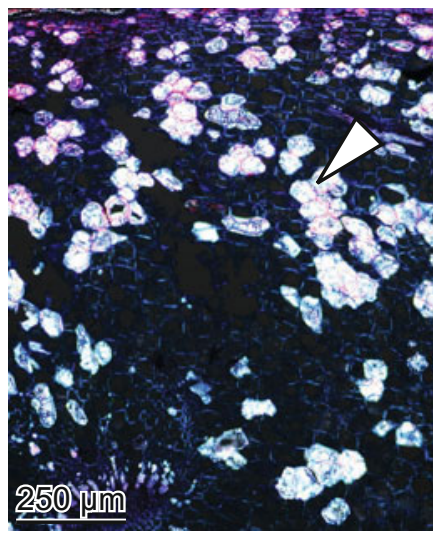

4.85 Sclereids in the peripheral part of the fruit of Mespilus germanica, polarized light).

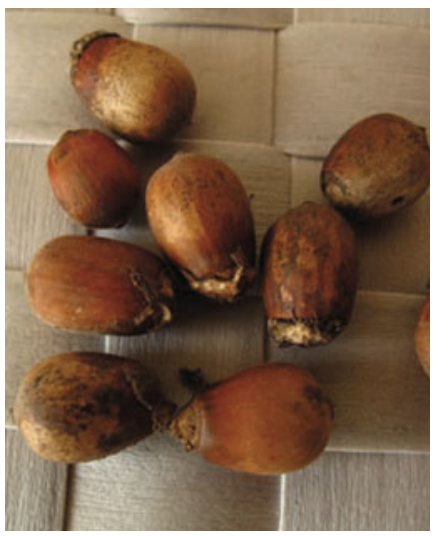

4.86 Fruits of the hazelnut (Corylus avellana).

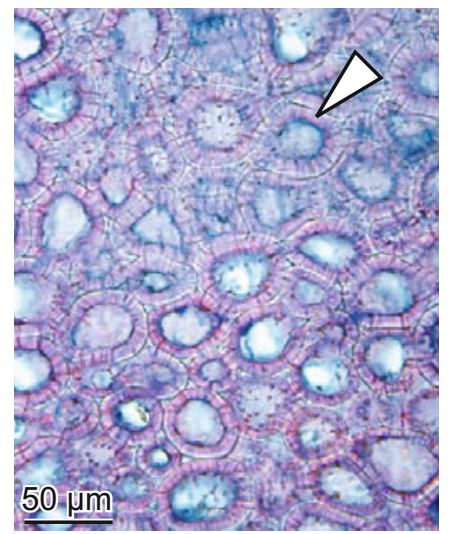

4.87 Sclereids in the shell of a hazelnut.
Single and groups of sclereids

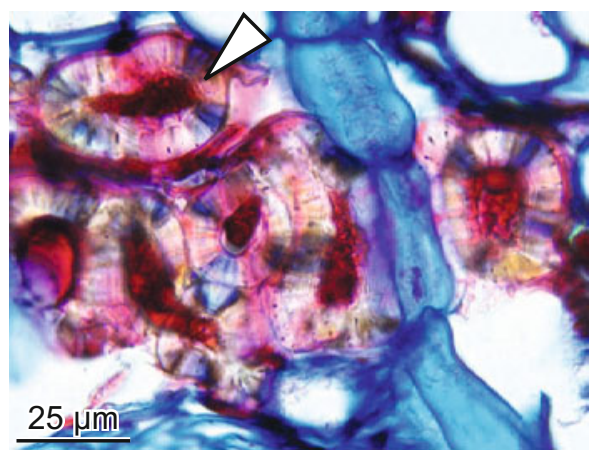

4.88 Group of sclereids in the bark of Picea abies.

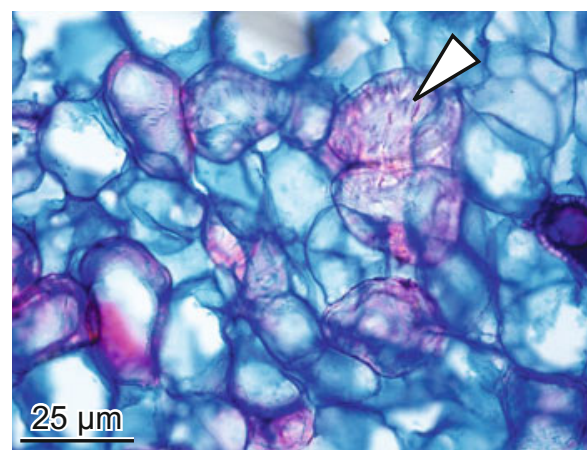

4.89 Isolated sclereids in the fruit of Mespilus germanica. layers

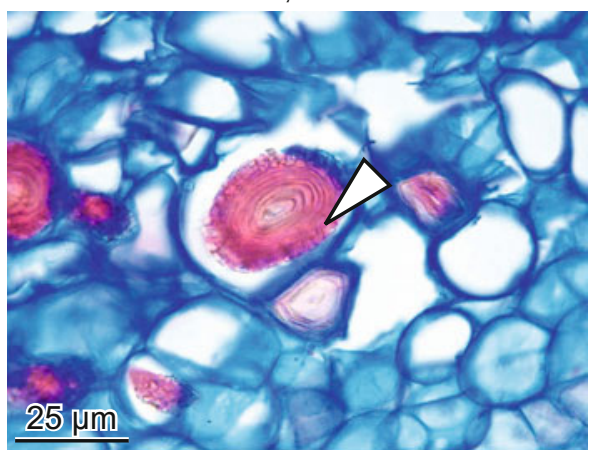

4.90 Isolated sclereids with distinct layers in a leaf of Welwitschia mirabilis. 


\subsection{Vessels - Water conduction}

Plant life on terrestrial sites would not exist without the water conducting vessels. However, it is generally difficult to see vessels with bare eyes, because their diameter is usually below the resolution of human eyes. Vessels consist of vessel elements. Fully developed vessel elements are dead and more or less elongated. They are composed of lignified cell walls, perforation plates at their distal ends and pits at the longitudinal walls. Lignification of the walls of vessel elements prevents cell collapse.

Vessels occur in the xylem of most spore plants (ferns, horsetails, lycopods) and most monocotyledons and dicotyledons, except in conifers and few others where they are replaced by tracheids. Vessels occur in all growth forms. Diameters are usually large in lianas $(>200-500 \mu \mathrm{m})$, smaller in trees $(50-200 \mu \mathrm{m})$ and small in herbs $(20-50 \mu \mathrm{m})$. The length of vessel elements varies from $<100 \mu \mathrm{m}$ in small herbs to $>1,500 \mu \mathrm{m}$ in trees. Vessel elements are normally short in ring-porous and long in diffuseporous tree species.

Vessels conduct water mainly in axial direction from the root to the leaves. Lateral perforations (bordered pits) also indicate a lateral water transport. Vessels exist in the xylem of all plant organs in various dimensions. Vessels are normally larger in roots than in stems, and even smaller in leaves.

For a discussion of cell-wall structures see Chapter 5.1.
Macroscopic aspect

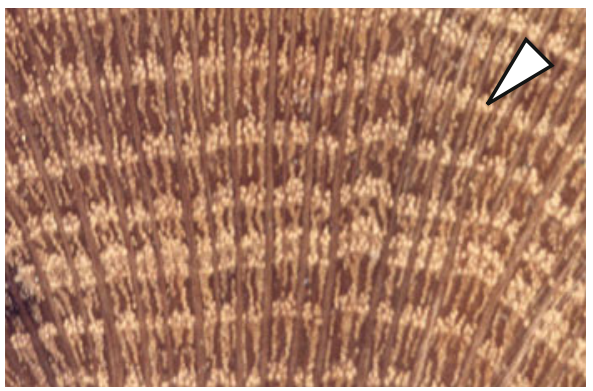

4.91 Vessels in the earlywood of ring-porous species (e.g. Quercus sp.) are visible to the bare eye.
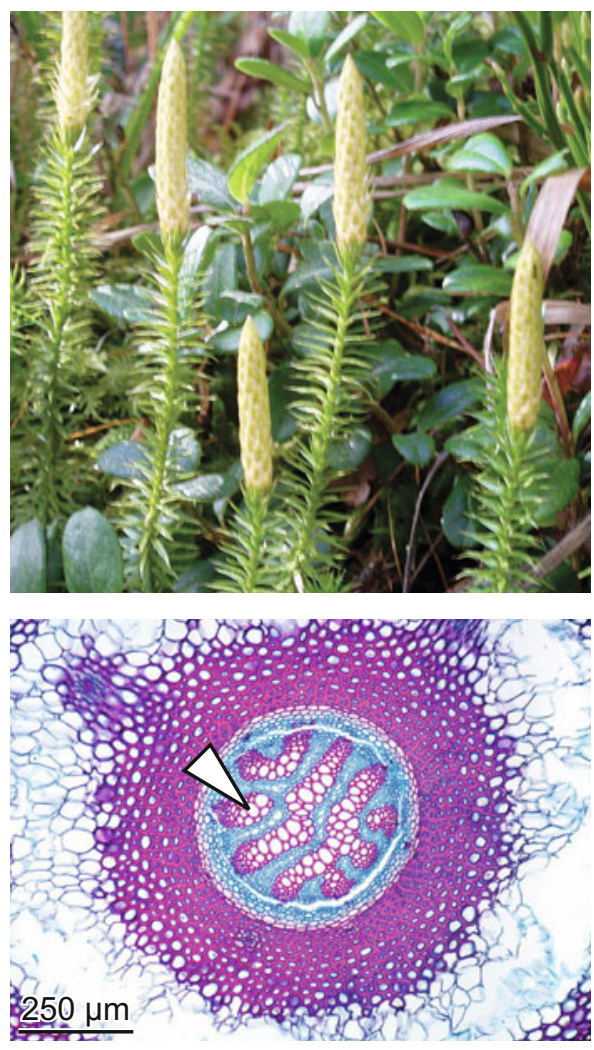

4.94 Lycopods: clubmoss Lycopodium clavatum.

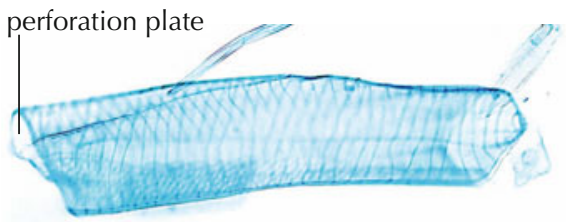

Anatomy of vessel elements
4.92 Long vessel element $(500 \mu \mathrm{m})$ with helical thickenings in Tilia sp.

\section{Vessels occur in all vascular plants}
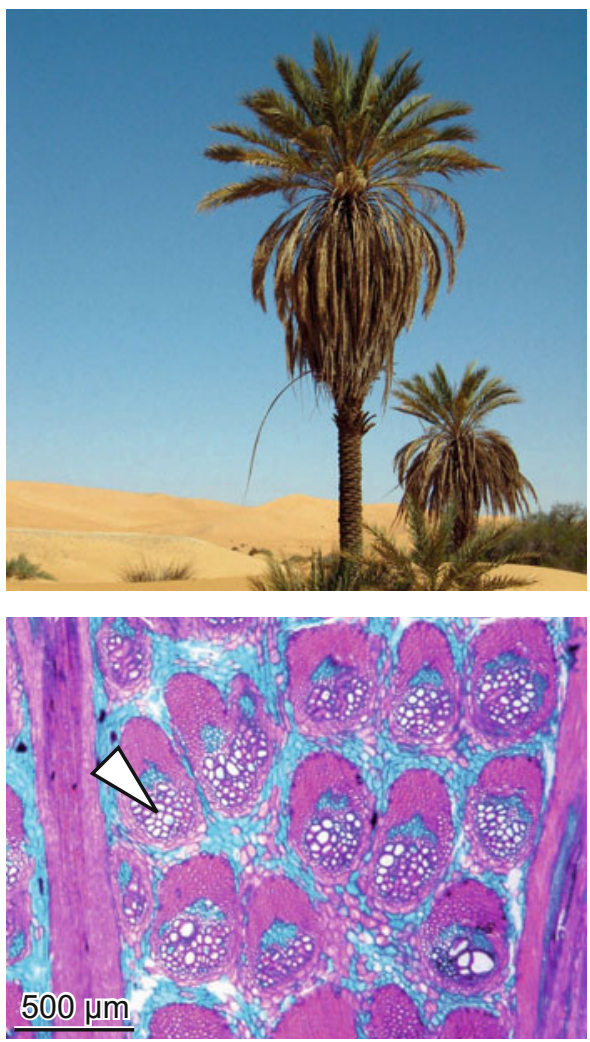

4.95 Monocotyledons: stem of palm Phoenix dactylifera.

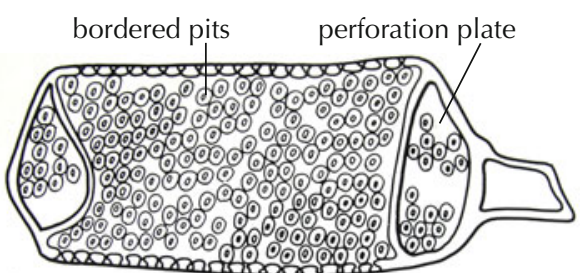

4.93 Short and wide vessel in the earlywood of Fraxinus excelsior. Reprinted from Greguss 1945.
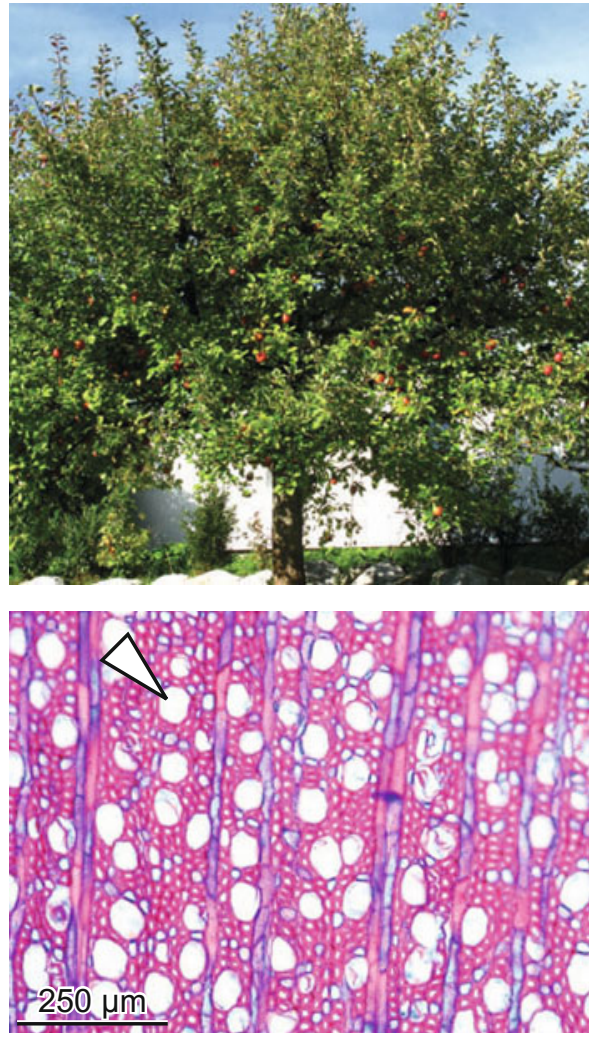

4.96 Dicotyledons: stem of apple tree Malus domestica. 
Vessels occur in all growth forms
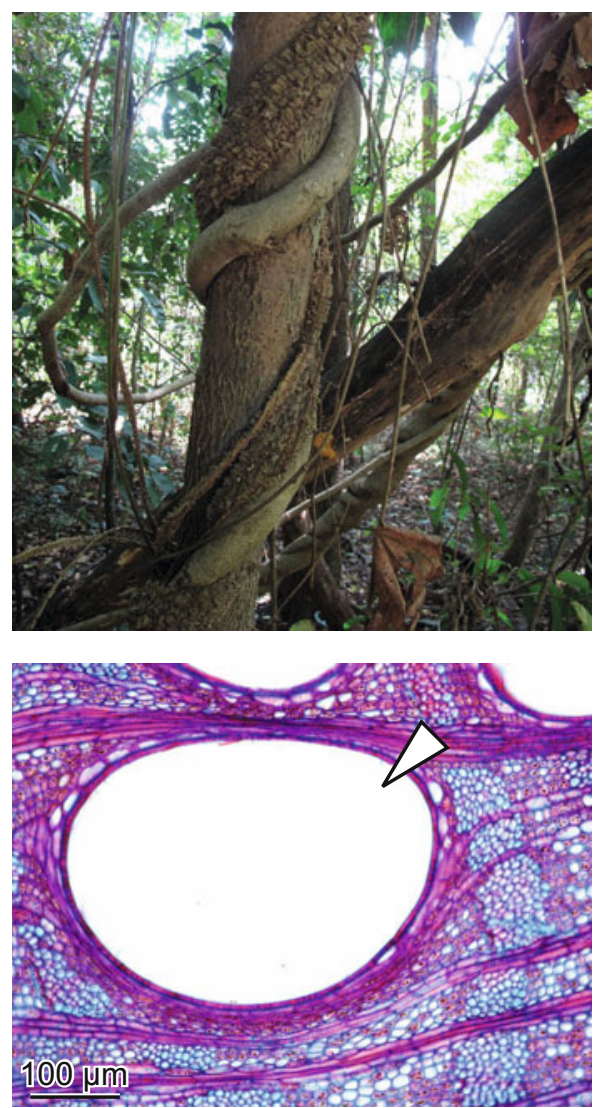

4.97 Very large vessel diameters (550 um) in lianas Celastrus sp. (top) and Thunbergia sp. (bottom).
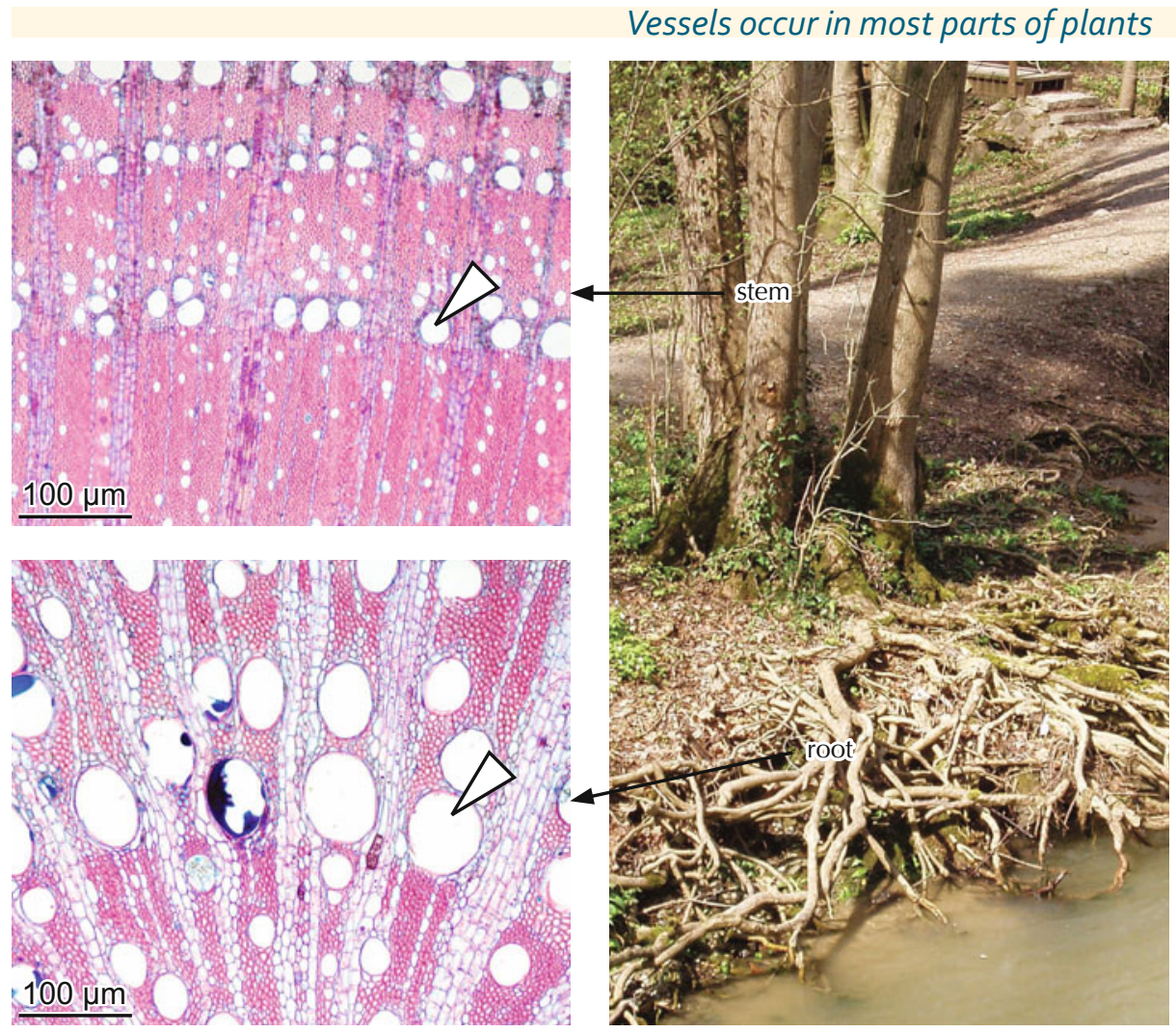

4.100 Diameter of earlywood vessels in the stem

(top) is $70 \mu \mathrm{m}$, in the root (bottom) $250 \mu \mathrm{m}$ in Prunus amygdalus.
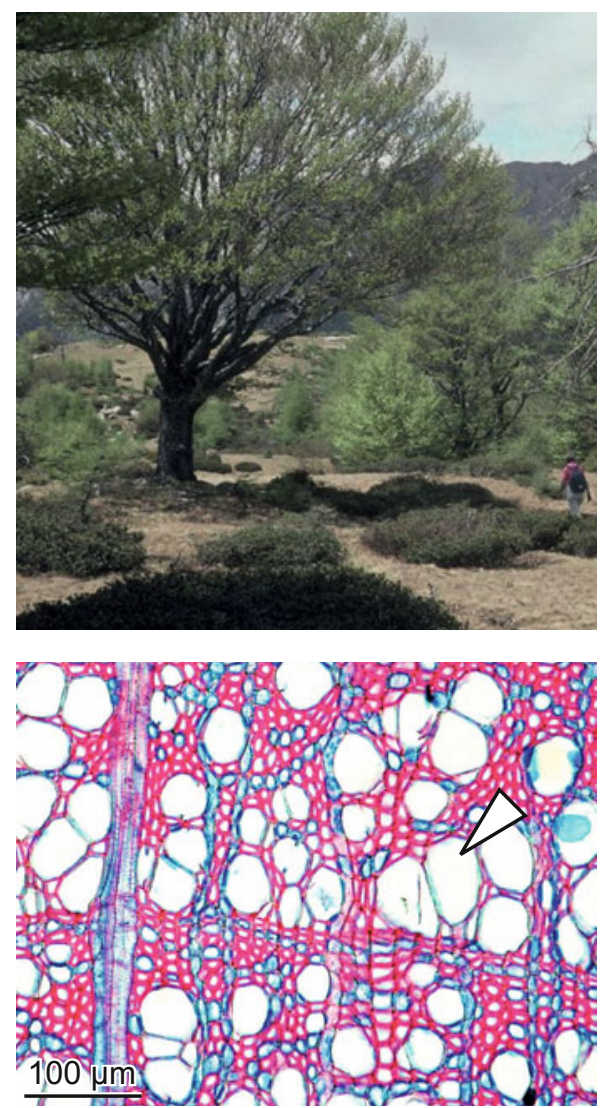

4.98 Large vessel diameter (80 um) in the dicotyledonous tree Fagus sylvatica.

Vessels occur in most parts of plants
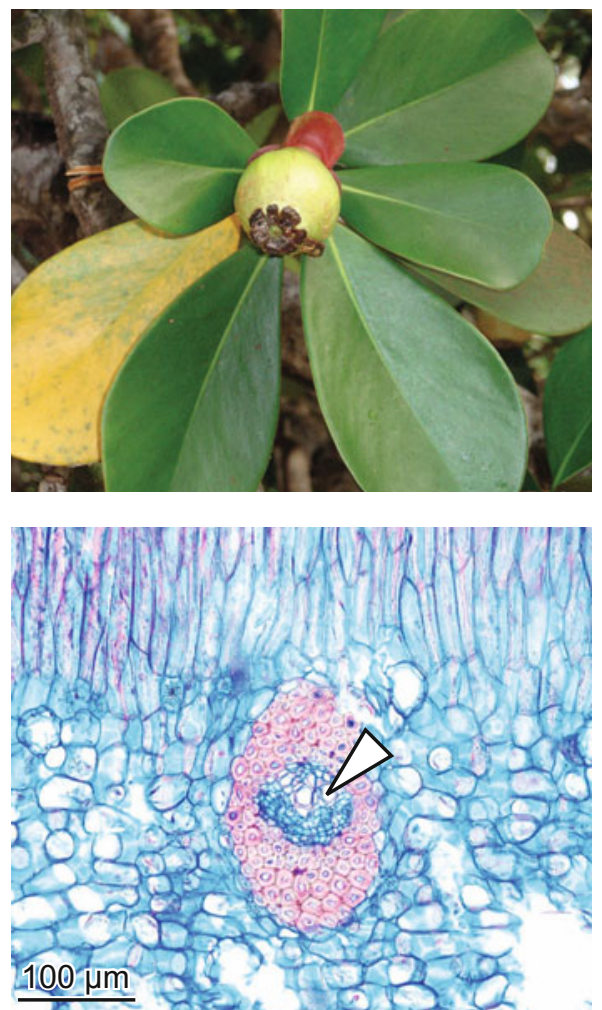

4.101 Small vessel diameters (20 um) in a vascular bundle of a thick leaf of Clusea rosea.
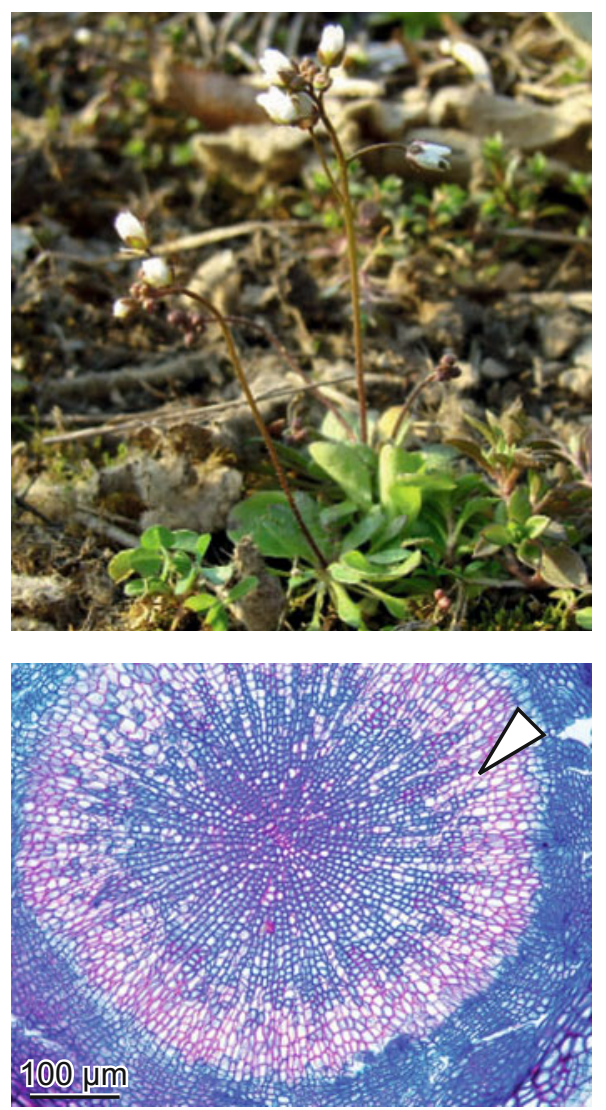

4.99 Very small vessel diameters $(20 \mu \mathrm{m})$ in the $5 \mathrm{~cm}$-tall annual herb Erophila verna. 


\subsection{Cork cells - Defense against organisms, heat and cold}

Cork is a perfect insulation material. We use it to seal wine bottles and to insulate walls and floors. Most of the industrially used cork is a product of cork oak (Quercus suber). Plants insulate their stems against extreme environmental conditions like intense radiation, blasting by sand and ice crystals, fire or flooding. Cork cells (phellem) occur outside of the phloem and cortex of most taxa and growth forms in conifers and dicotyledons. They are rare in monocotyledonous plants, and occur there only in trees. Cork cell walls consist of suberin, which is difficult to decompose for many fungi. Cork cells of any form can be thin- or thick-walled.

Cork formation occurs usually on the outside of stems. However, a few species produce cork rhythmically within the xylem. Small, long-lived herbs compartmentalize their center by forming cork internally within the stem.

\section{Cork cells in stems of seed plants of all growth forms}
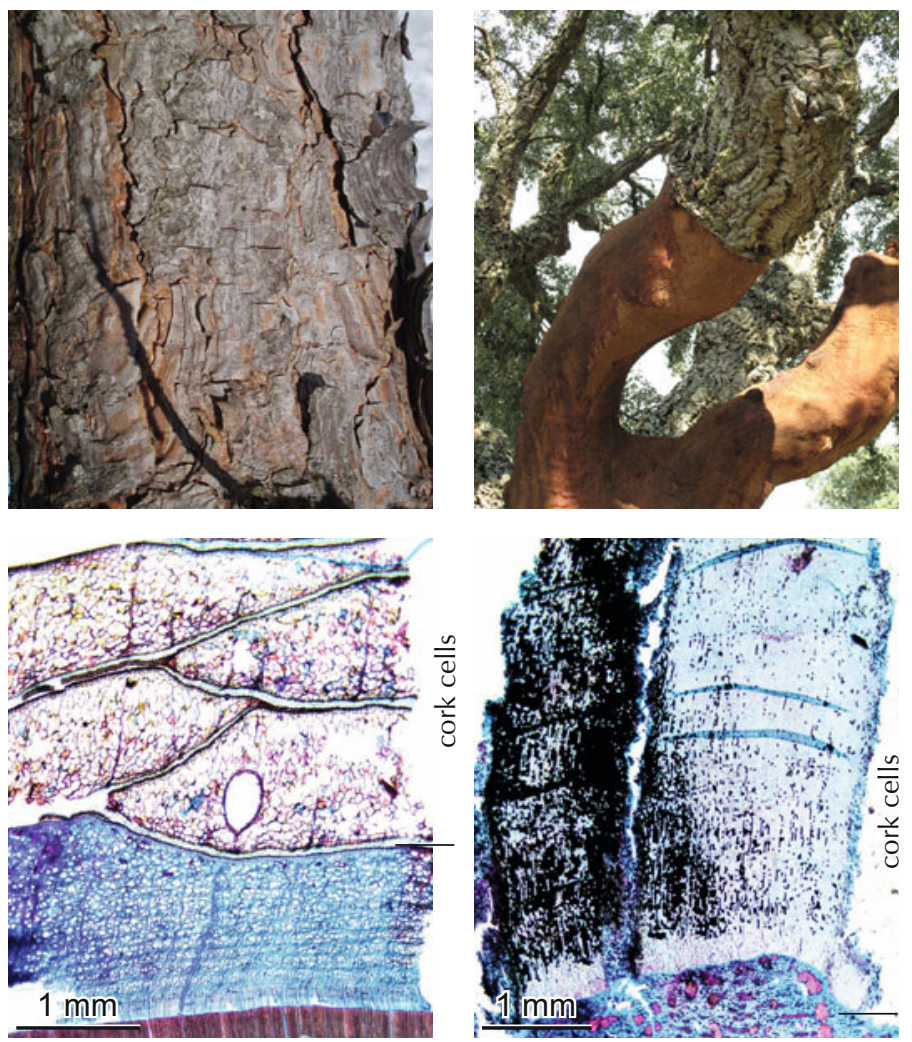

4.102 Conifers: Layered bark of Pinus sylvestris.
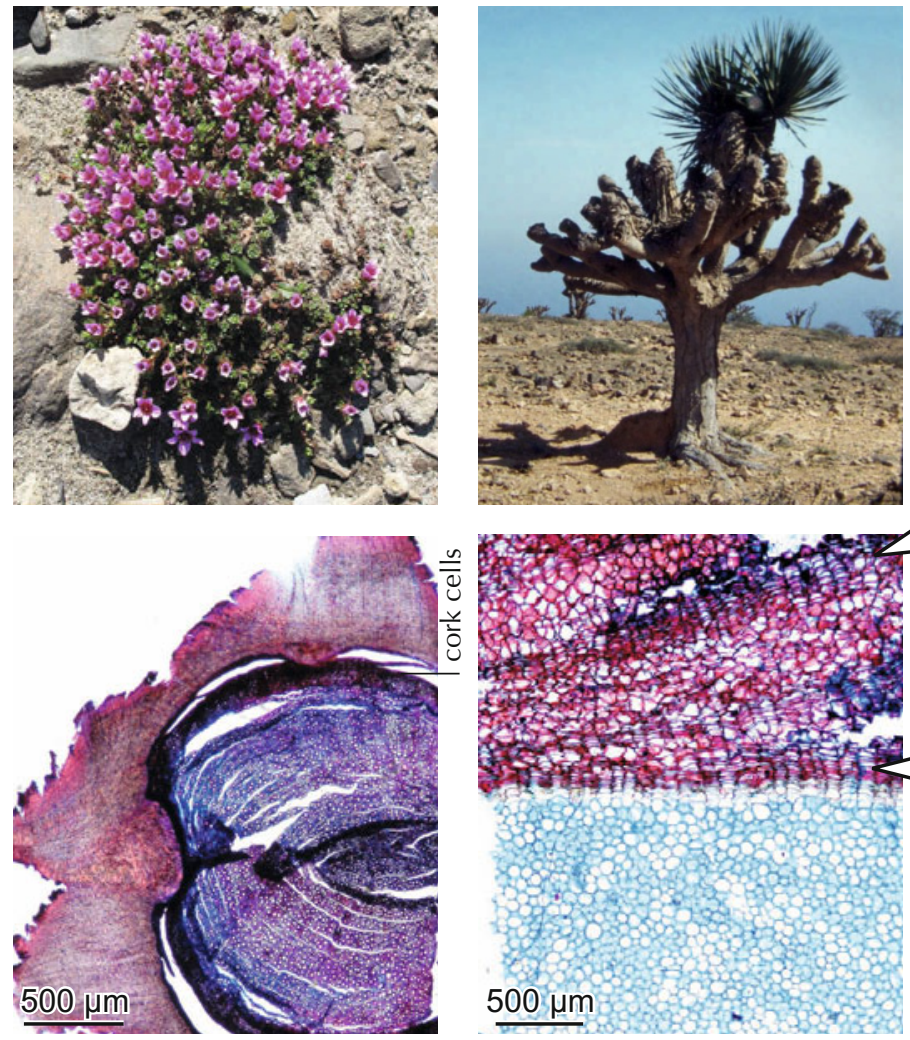

4.104 Dicotyledonous plants: Layered bark of a small cushion of the alpine Saxifraga oppositifolia.

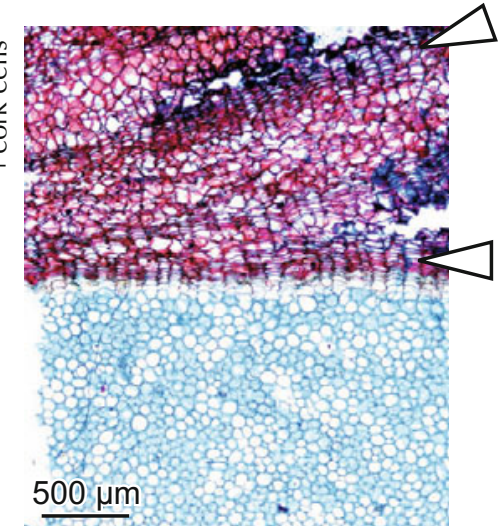

4.105 Monocotyledonous plants: Cork cells in the tree Dracaena serrulata.
Thin- and thick-walled cork cells

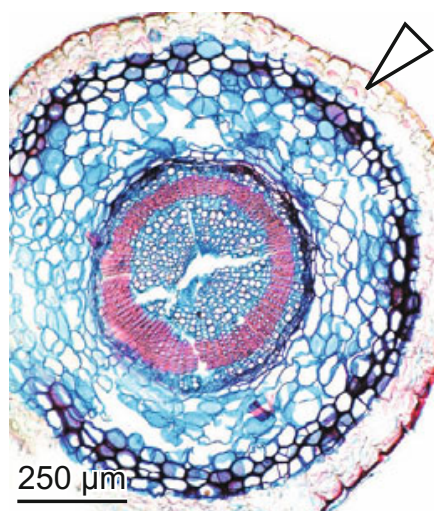

4.106 A small mantle of thin-walled cork cells surrounds the water-storing cortex of the succulent Sedum acre.

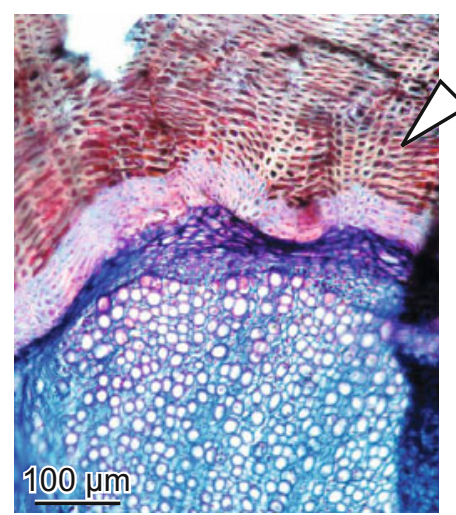

4.107 A large zone of thick-walled, rectangular cork cells surrounds the soft, unlignified xylem of the alpine cushion plant Saxifraga caesia.

Cork cells within the xylem

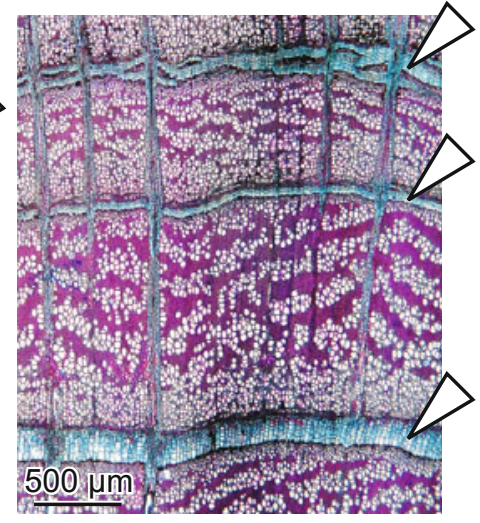

4.108 Tangential cork layers between compartments of xylem in Artemisia tridentata.

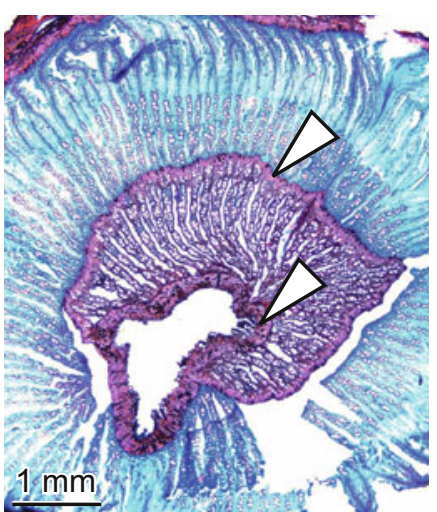

4.109 Cork layers in a stem separate the living from the dead xylem in the center of the stem of Scorzonera virgata. 


\subsection{Sieve cells, sieve tubes and companion cells - Conduction of assimilates}

Sieve elements are part of the bast. Neolithic settlers knew sieve cells and bast fibers very well and used the bast of several plants to braid baskets and tissues. Today, papier mâché ("chewed paper") is probably the only remaining useful product.

Sieve cells and sieve tubes are a major part of the phloem, which mainly conducts assimilates from leaves to parenchyma cells. Sieve elements are accompanied by parenchyma cells and companion cells. Sieve cells have sieve fields on their lateral sides, while sieve tubes have plates at their distal ends and on their lateral walls. However, the anatomical differentiation in cross sections is generally difficult. Sieve tubes and sieve cells are long, thin-walled and unlignified. Adult sieve elements do not contain nuclei. The metabolism of the sieve elements is maintained by the nuclei in the companion cells. Companion cells are smaller and always adjacent to sieve tubes.

Sieve cells occur in all vascular plants from ferns to dicotyledons. Sieve cells and sieve tubes often collapse following their death. More information is given in Chapter 6.2.8.

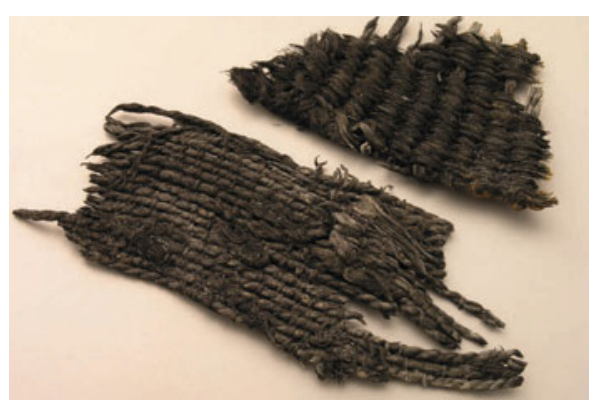

4.110 Neolithic tissues made of Tilia bast. Photo: Amt für Städtebau Unterwasserarchäologie, Univ. Zürich.

\section{Macroscopic aspect of the phloem}

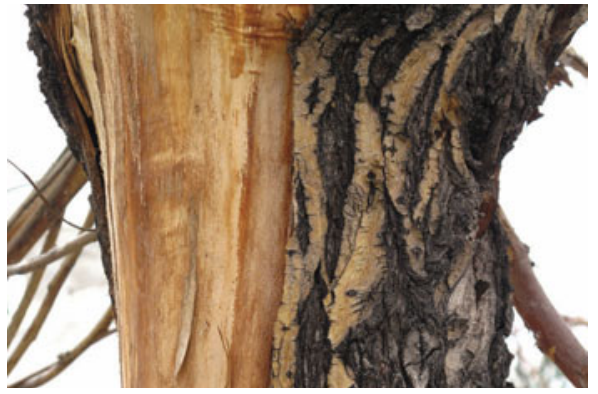

4.111 Stripped bark of Populus sp. Bast fibers dismantled from the xylem in the cambial zone.

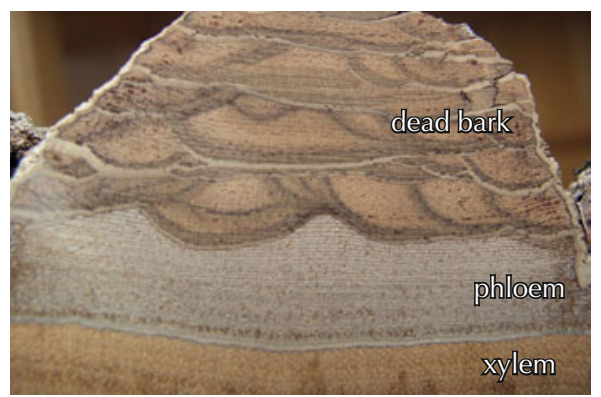

4.112 Large layered phloem between the xylem and cork in Juglans regia.

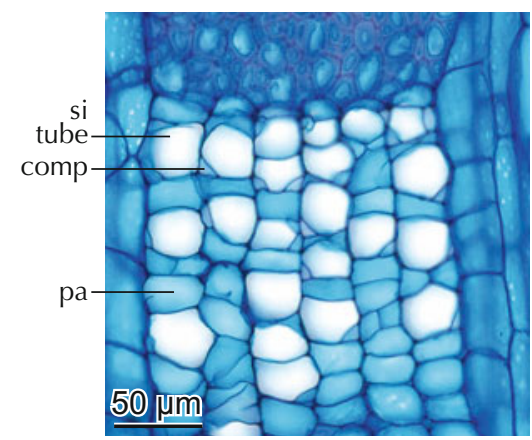

4.113 Phloem of the tree Adansonia digitata, consisting of sieve tubes, companion cells and parenchyma cells.

Anatomy of sieve elements and companion cells

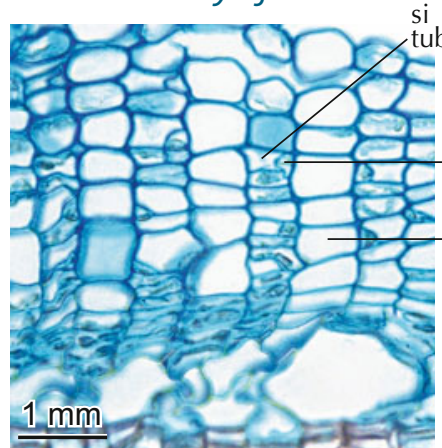

4.114 Phloem of the shrub Lonicera alpigena, consisting of sieve tubes, companion cells and parenchyma cells.

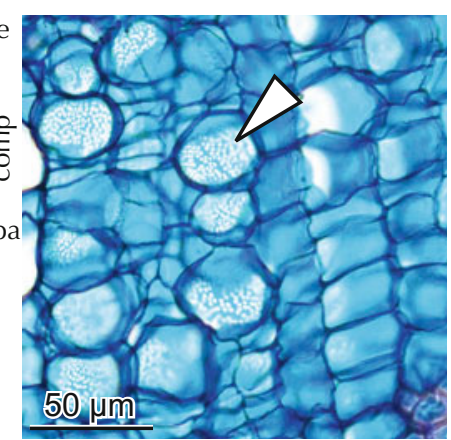

4.115 Sieve plates of sieve tubes in Adansonia digitata.

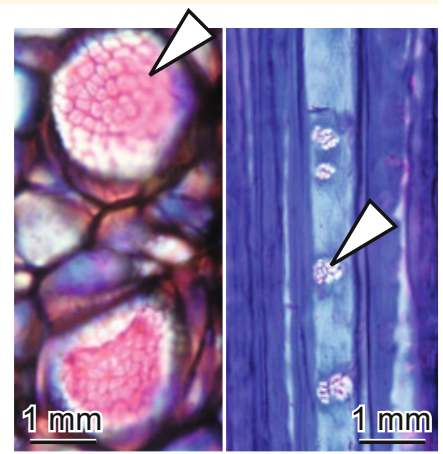

4.116 Sieve elements of the dicotyledonous herb Bryonia dioeca (left) with sieve plates at distal ends, and of the conifer Larix decidua with lateral sieve plates (right).

Sieve elements in ferns, conifers, dicotyledonous and monocotyledonous plants

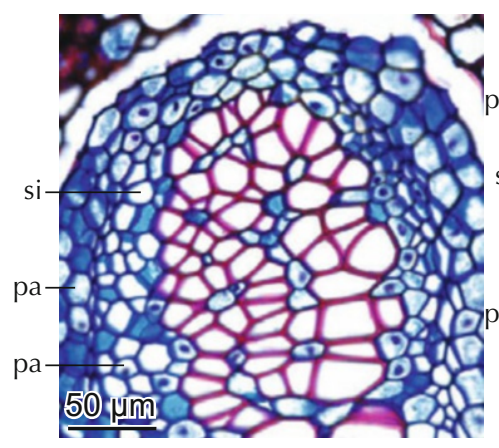

4.117 Sieve cells in the phloem of the fern Cryptogramma crispa.

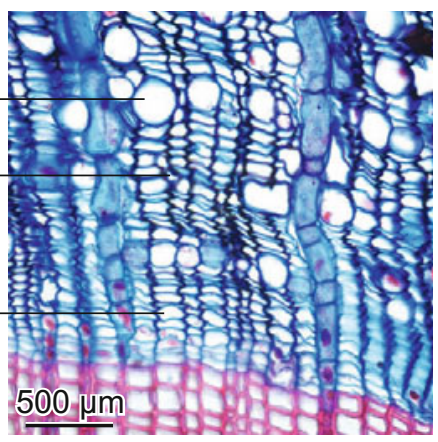

4.118 Sieve cells in the phloem of the conifer Picea abies.

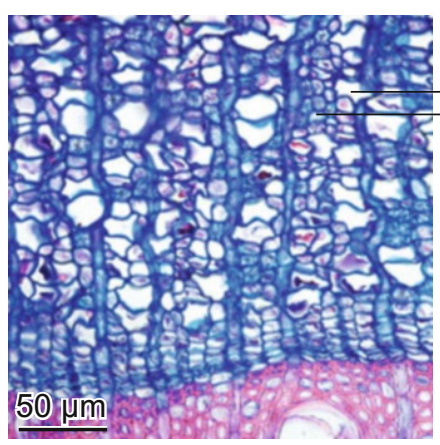

4.119 Sieve tube in the phloem of the dicotyledonous Quercus ilex.

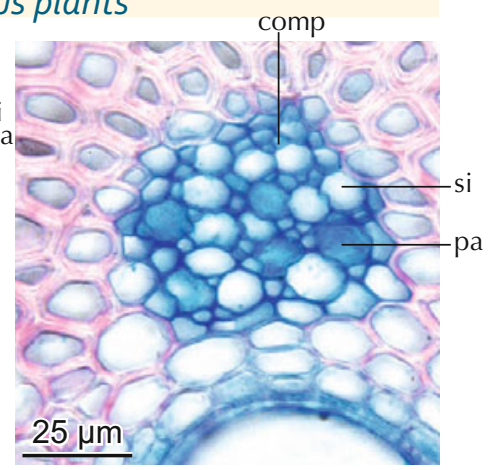

4.120 Sieve tubes in a vascular bundle of the monocotyledonous Arundo donax. 


\subsection{Secretory cells - Defense}

Today, the best known products of secretory cells are resin condensates, e.g. colophony, amber, incense, and oils in orange skins. The resins are excreted from resin ducts in trees. Fifty years ago, latex as a product of secretory canals was intensively used as gum for tires and chewing gum.

Plant secretory cells are formed either externally, from epidermal tissues, or internally, by primary or secondary meristems. Described in this section are mainly internal secretory cells. They sporadically occur in the whole taxonomic system of

\section{Resin use in art and religion}

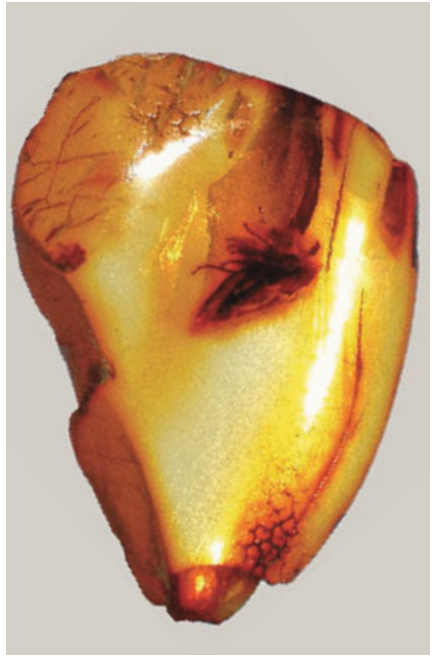

4.121 Amber is a fossilised, condensed resin, produced from various conifers 100 million years ago. It has been regarded as a magic "stone" since Neolithic times. Photo: L. Monshausen.

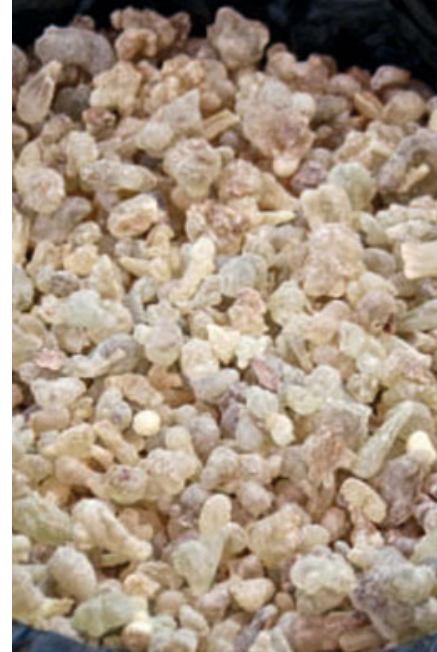

4.122 Frankincense is a product of resin ducts in the bark of the desert tree Boswellia sacra. Incense smoke is used for many ritual acts in a number of different religions. Photo: S. Fleckney.

terrestrial plants from ferns to dicotyledonous plants. Secretory cells are thin-walled, unlignified cells. Single cells occur in the xylem of a few trees and produce oil. Laticifers (latex ducts) form long, uni- or multicellular tubes. Very frequent are ducts that are surrounded by resin-producing, long-lived epithelial and parenchyma cells. Many slime-producing secretory cells are anatomically identical to normal parenchyma cells.

Secretory cells occur around ducts in the pith, xylem, phloem and cortex of stems, roots, leaves and fruits.

Essential oils

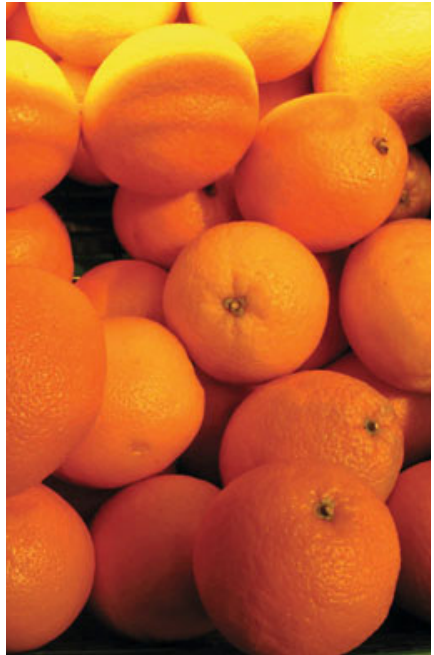

4.123 Ducts in the skin of oranges (Citrus sinensis) produce essential oils.
Latex

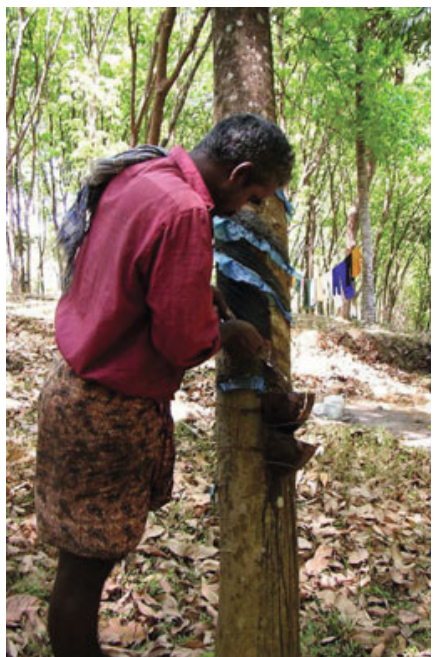

4.124 Caoutchouc harvesting on a tree of Hevea brasiliensis.

Resin ducts in the xylem of conifers

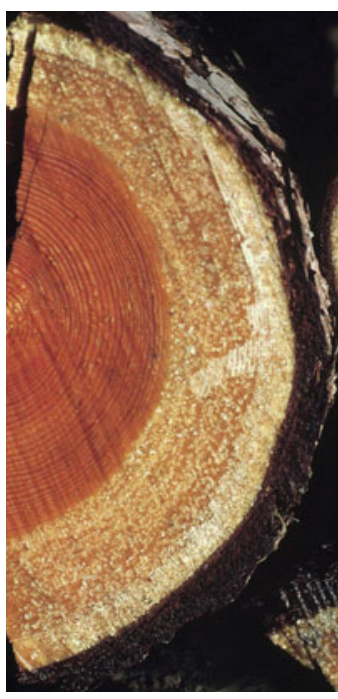

4.125 Resin in the sapwood of the conifer Pinus sylvestris

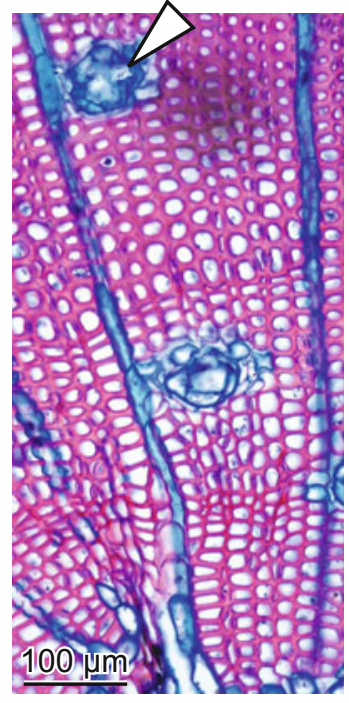

4.126 Resin ducts in the xylem of the conifer Pinus mugo.

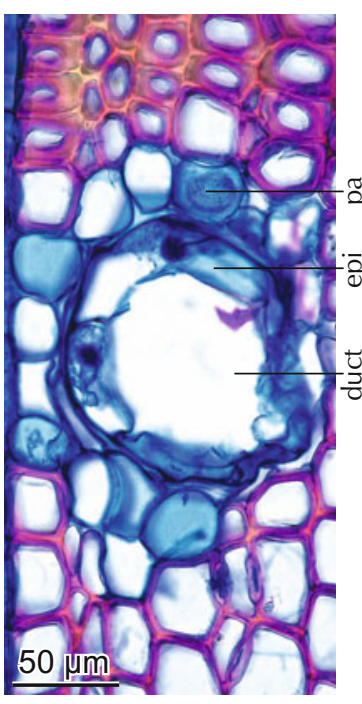

4.127 Living epithelial and parenchyma cells around a resin duct in Pinus sylvestris.

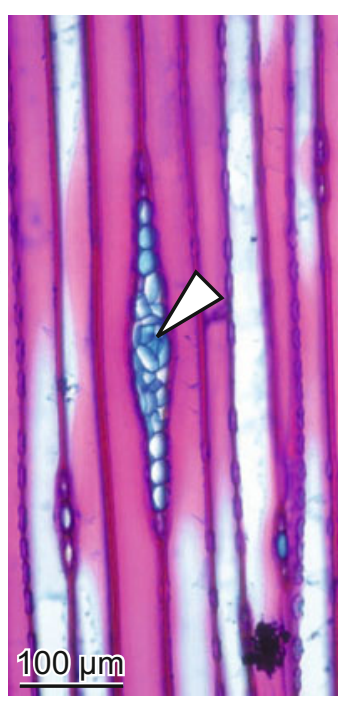

4.128 Resin duct in a ray in Pinus sylvestris, tangential section.

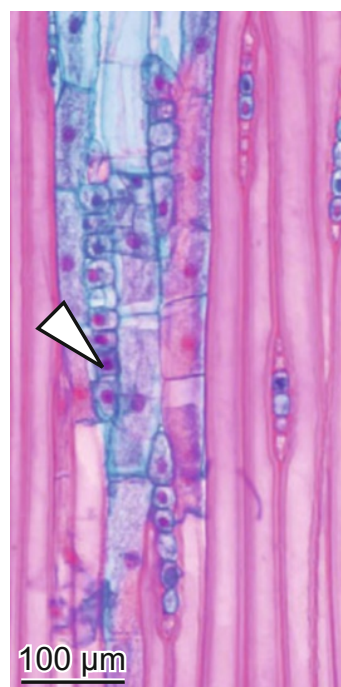

4.129 Living epithelial and parenchyma cells around a resin duct of Pinus sylvestris, radial section. 
Anatomy of ducts in stems of dicotyledonous plants

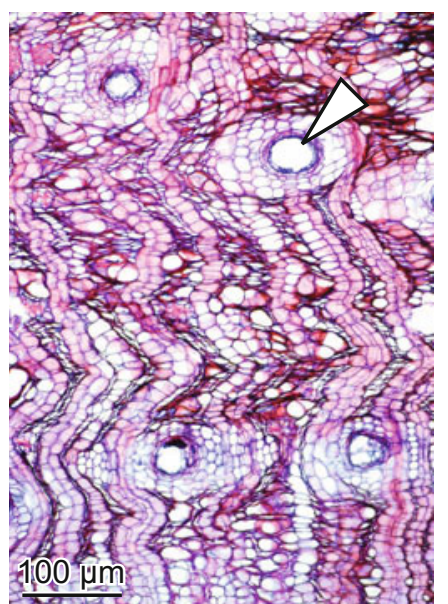

4.130 Resin ducts in the phloem of the incense tree Boswellia sacra.

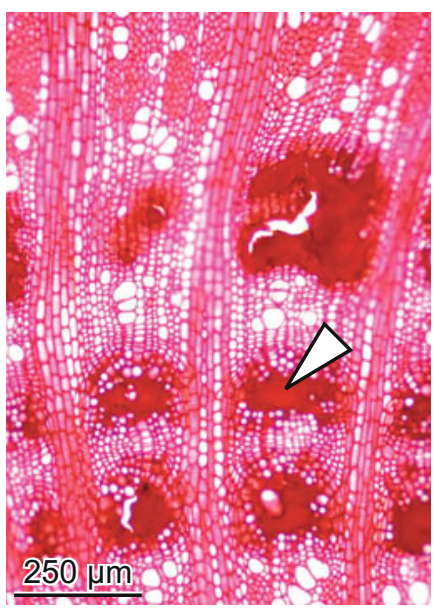

4.131 Traumatic "resin" ducts in the xylem of an almond tree (Prunus amygdalus).

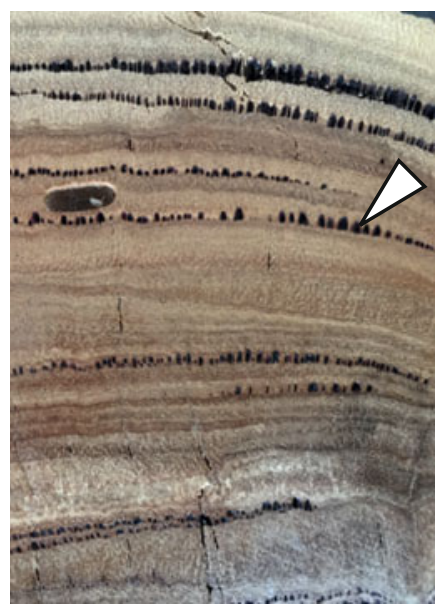

4.132 Macroscopic aspect of traumatic "resin" ducts (kino veins) in the xylem of Eucalyptus obliqua. Photo: P. Majewski.

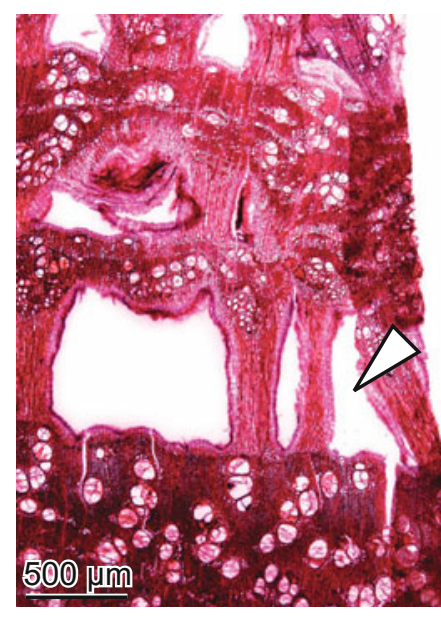

4.133 Microscopic aspect of traumatic "resin" ducts (kino vein) in the xylem of a Eucalyptus sp.
Anatomy of ducts in various parts of plants

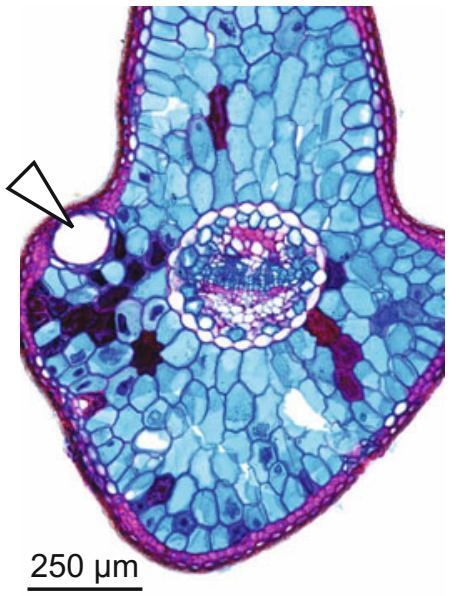

4.134 Resin duct in a needle of the conifer Picea abies.

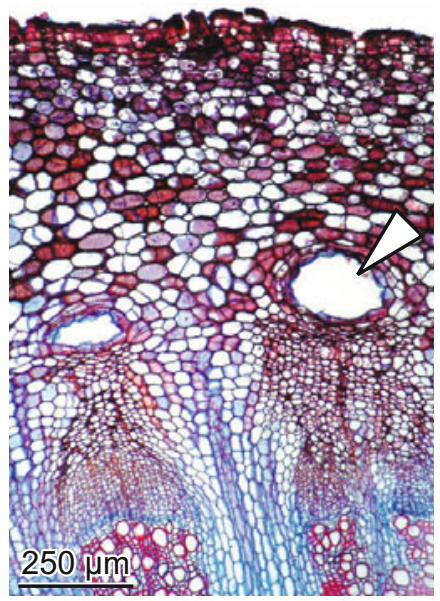

4.135 Duct in the cortex of the bark of the herb Petasites paradoxus.

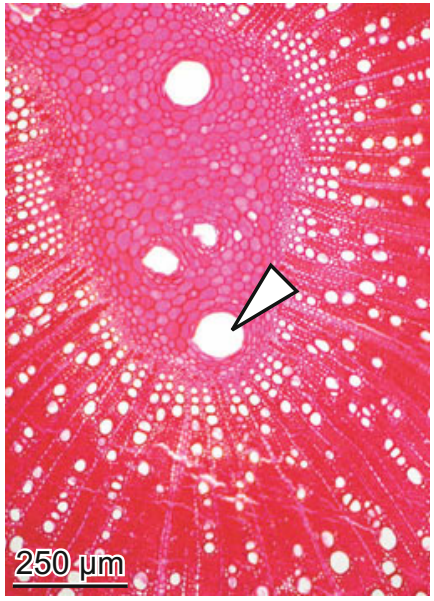

4.136 Ducts in the pith of a twig of Grewia villosa.

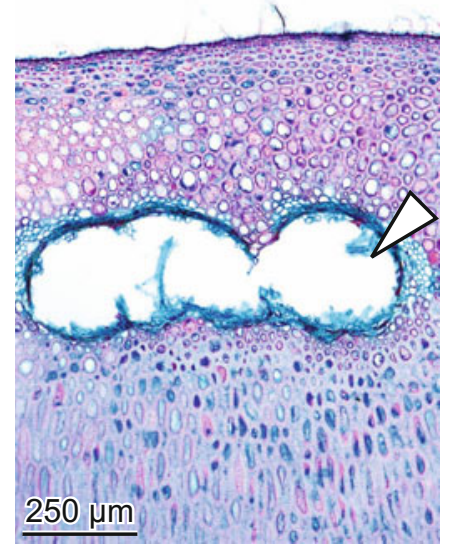

4.137 Ducts in the shell of a hazelnut (Corylus avellana).
Anatomy of oil cells

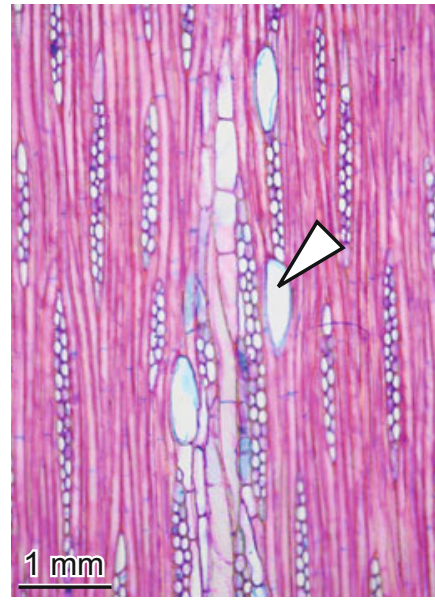

4.138 Enlarged oil cells in the xylem of the tree Phoebe nanmu, tangential section. It was the preferred wood for the construction of the Forbidden City in Beijing.

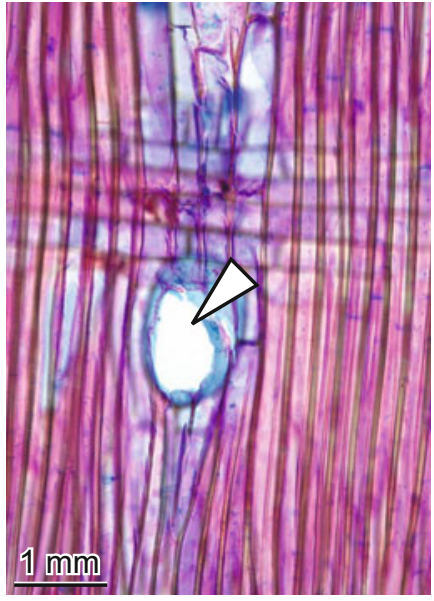

4.139 Enlarged oil cells in the xylem of Phoebe nanmu, radial section.

Anatomy of laticifers

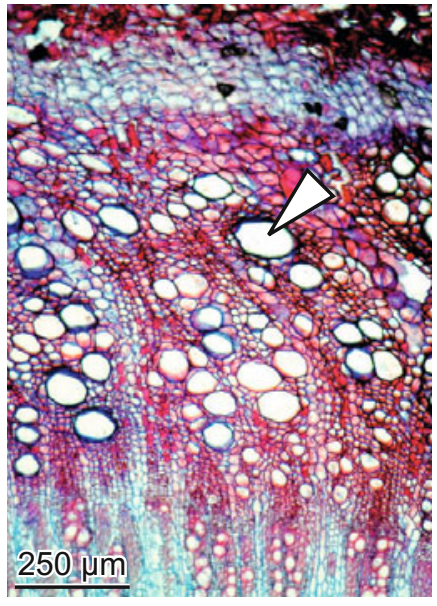

4.140 Latex-producing laticifers in the phloem and the cortex of the shrub Euphorbia armena.

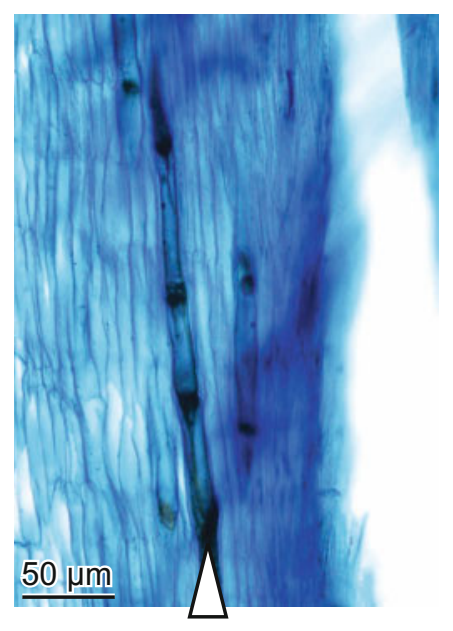

4.141 A single laticifer, consisting of several secretory elements in Scrophularia dentata. 


\subsection{Intercellulars and aerenchyma - Air circulation within the plant}

The very light-weighted shoots of reed (Phragmites communis) and many other grass-like shore plants have been used for the construction of boats, and the insulation of roofs and floors. Hay from wet meadows in the European Alps is used as bedding in cattle stables. These practical uses are based on the hollow stems, and the presence of aerenchyma in the shoots. Intercellulars of any form occur mainly in wetland plants. They guarantee the gas exchange from the stomata in the leaves to all cells within the plant. Large intercellulars are defined as aerenchyma. Hollow shoots and aerenchyma in water plants allow them to float. Small intercellulars occur mainly in leaves, pith and cortex of plants in all taxonomic units of vascular plants, and aerenchyma with particular structures occur in plants of wet environments, e.g. in swamps and lakes (helophytes and hydrophytes).

Intercellulars are small spaces between round cells. Aerenchyma consists of parenchyma cells surrounding the intercellulars. They form nets, sponge-like tissues in thick stems, star-like groups, channels, irregular and radial spaces and lacunas.

\section{Use of wetland plants}

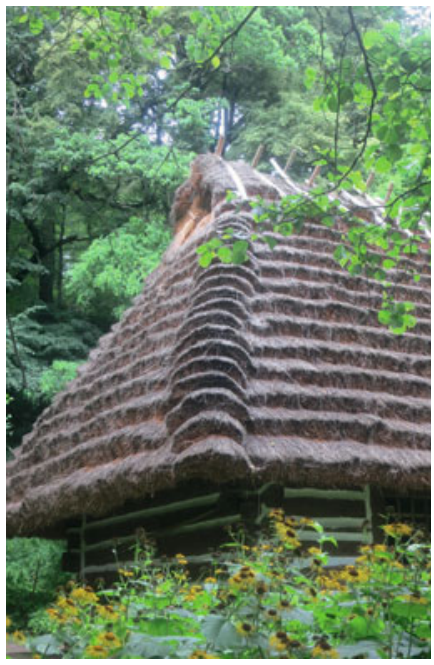

4.142 Roofing with reed (Phragmites communis).

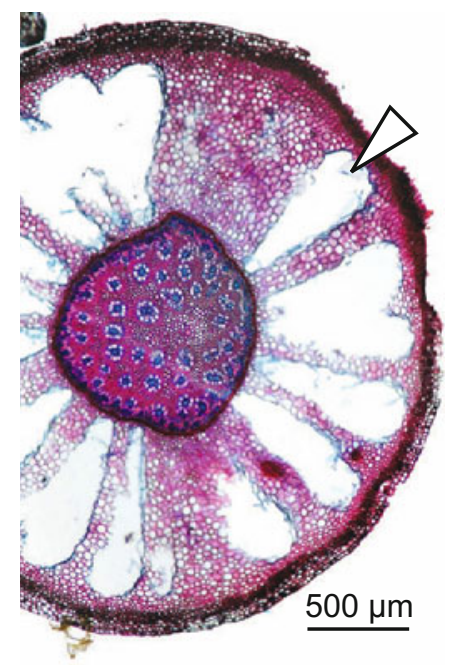

4.146 Air-filled radial spaces in the cortex of a rhizome of Juncus arcticus.

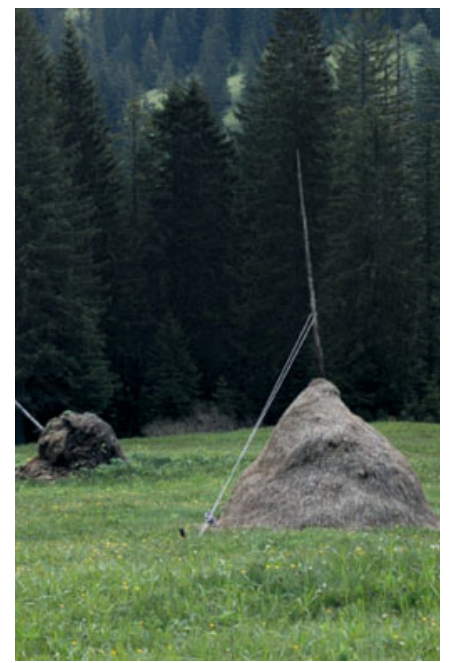

4.143 Stacks of dry, stiff, nutrientpoor grasses and sedges in a wet montane meadow. The material is used instead of cereal straw for bedding in cattle stables. Photo: $\mathrm{M}$. Küchler.

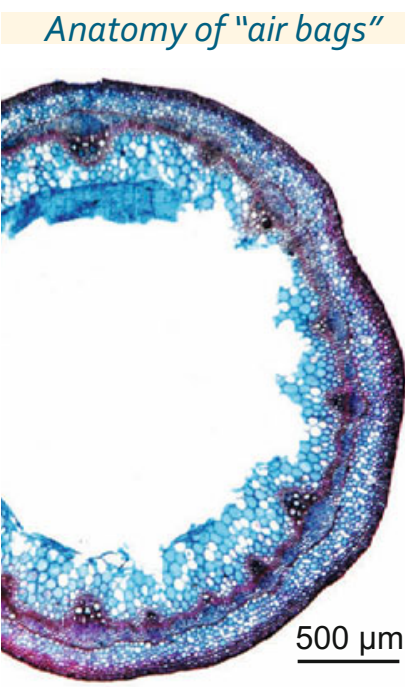

4.144 Hollow pith as the result of extreme stem expansion in Polygonum amphibium.

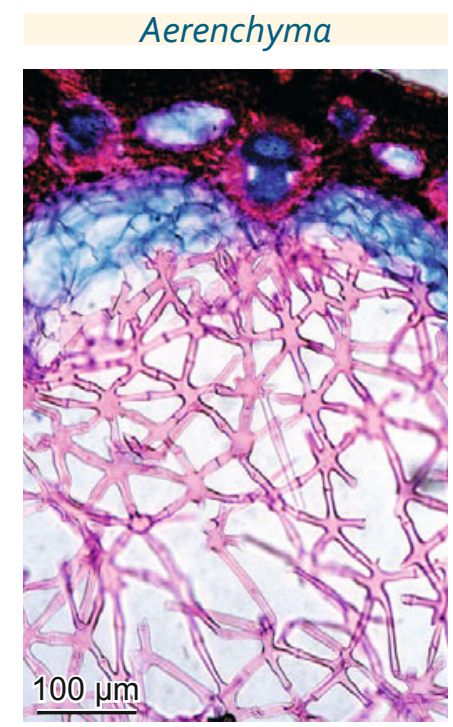

4.145 Stellate combined cells form an air-filled shoot center in Juncus conglomeratus.

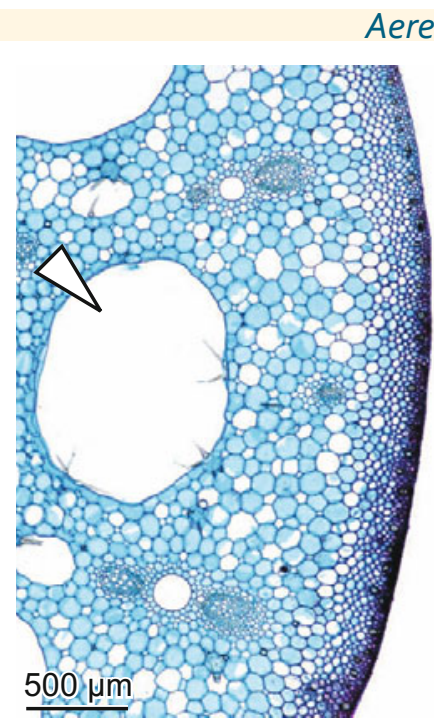

4.147 Large air tubes conduct air from the leaf to the root in $\mathrm{Nym}$ phaea alba.

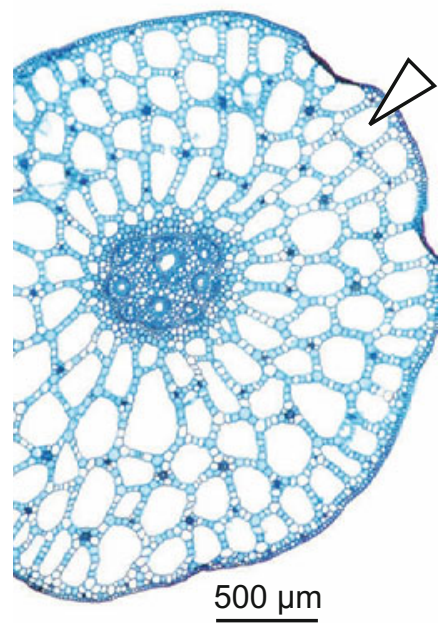

4.148 Small air tubes conduct air from the leaf to the root in Potamogeton natans.

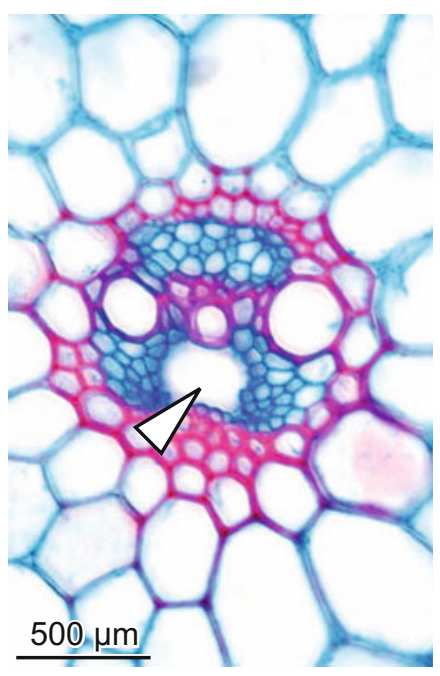

4.149 Small lacunas within vascular bundles conduct air from the leaf to the roots in Dacytlis glomerata. 
Open Access This chapter is licensed under the terms of the Creative Commons Attribution 4.0 International License (http://creativecommons.org/licenses/by/4.0/), which permits use, sharing, adaptation, distribution and reproduction in any medium or format, as long as you give appropriate credit to the original author(s) and the source, provide a link to the Creative Commons license and indicate if changes were made.

The images or other third party material in this chapter are included in the chapter's Creative Commons license, unless indicated otherwise in a credit line to the material. If material is not included in the chapter's Creative Commons license and your intended use is not permitted by statutory regulation or exceeds the permitted use, you will need to obtain permission directly from the copyright holder. 